Florida International University FIU Digital Commons

\title{
A Comparative Study of Concurrent Acoustic and Diver Survey Data, and Fish Community Descriptions of a High Latitude Coral Reef, Florida, USA
}

Adam M.Zenone

Florida International University, a.m.zenone@gmail.com

DOI: $10.25148 /$ etd.FI15032182

Follow this and additional works at: https:// digitalcommons.fiu.edu/etd

Part of the Marine Biology Commons, and the Other Ecology and Evolutionary Biology Commons

\section{Recommended Citation}

Zenone, Adam M., "A Comparative Study of Concurrent Acoustic and Diver Survey Data, and Fish Community Descriptions of a High Latitude Coral Reef, Florida, USA" (2015). FIU Electronic Theses and Dissertations. 1855.

https://digitalcommons.fiu.edu/etd/1855 


\title{
FLORIDA INTERNATIONAL UNIVERSITY
}

Miami, Florida

\begin{abstract}
A COMPARATIVE STUDY OF CONCURRENT ACOUSTIC AND DIVER SURVEY DATA, AND FISH COMMUNITY DESCRIPTIONS OF A HIGH LATITUDE CORAL REEF, FLORIDA, USA
\end{abstract}

A thesis submitted in partial fulfillment of the

requirements for the degree

of

MASTER OF SCIENCE

in

BIOLOGY

by

Adam Zenone

2015 
To: Dean Michael Heithaus

College of Arts and Sciences

This thesis, written by Adam Zenone, and entitled: A Comparative Study of Concurrent Acoustic and Diver Survey Data, and Fish Community Descriptions of a High Latitude Coral Reef, Florida, USA, having been approved in respect to style and intellectual content, is referred to you for judgement.

We have read this thesis and recommend that it be approved.

$\begin{array}{r}\text { William Anderson, Jr. } \\ \hline \text { Deron Burkepile }\end{array}$

Date of Defense: March 23, 2015

The thesis of Adam Zenone is approved.

Dean Michael Heithaus College of Arts and Sciences

Dean Lakshmi N. Reddi University Graduate School

Florida International University, 2015 


\section{DEDICATION}

This thesis is dedicated to my family, too numerous to fit in a single thesis dedication section, without whom I would have never been capable of escaping landlocked Pennsylvania to pursue my oceanic research interests, and whose constant support has been a source of great comfort. To my father Michael Zenone, whose subscription to Discovery Magazine and advice to "never stop asking questions" has led me to where I am today. To my mother, Angela Shuke, who has always been a source of advice, an always listening sounding board for my troubles, and whose support through my career has even extended to assistance in data collection field days for my research! Also, to my Aunt Renee, whose sense of adventure and whose own scientific graduate pursuits were a constant inspiration. 


\section{ACKNOLWEDGMENTS}

I would like to thank Kevin Boswell for his constant assistance and for taking me in despite little marine specific experience, and at the expense of many tools. Without his constant guidance and support, this thesis would never have been remotely possible. I would also like to thank Dr. Deron Burkepile for bringing his experience in coral reefs, and Dr. Bill Anderson for providing additional assistance and an outside perspective to keep my project grounded. Further, I would like to thank my lab-mates, current, past, and present for putting up with my loudness and constant questions, as without their support I would not have survived the day to day grind. A special thanks to the Florida International University Department of Biological Sciences, for providing the assistantship and education that allowed me to become a better scientist. Finally, a special thank you to the admirable performance of countless volunteers that tolerated my endless requests for assistance. 


\begin{abstract}
OF THE THESIS
A COMPARATIVE STUDY OF CONCURRENT ACOUSTIC AND DIVER SURVEY DATA AND FISH COMMUNITY DESCRIPTIONS OF A HIGH LATITUDE CORAL REEF, FLORIDA, USA
\end{abstract}

by

Adam Zenone

Florida International University, 2015

Miami, Florida

Kevin Boswell, Major Professor

Fisheries independent data on relatively unstudied nekton communities were used to explore the efficacy of new tools to be applied in the investigation of shallow coastal coral reef habitats. These data obtained through concurrent diver visual and acoustic surveys provided descriptions of spatial community distribution patterns across seasonal temporal scales in a previously undocumented region. Fish density estimates by both diver and acoustic methodologies showed a general agreement in ability to detect distributional patterns across reef tracts, though magnitude of density estimates were different. Fish communities in southeastern Florida showed significant trends in spatial distribution and seasonal abundance, with higher estimates of biomass obtained in the dry season. Further, community composition shifted across reef tracts and seasons as a function of the movements of several key reef species. 


\section{TABLE OF CONTENTS}

CHAPTER

PAGE

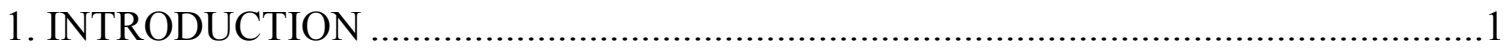

1.1 Coral reefs worldwide and in Southeastern Florida....................................

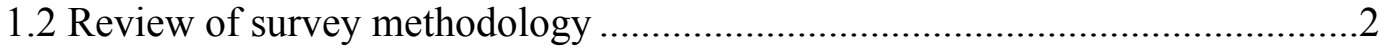

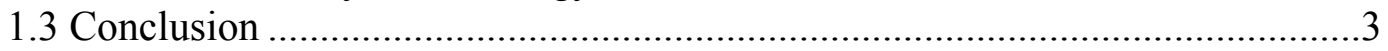

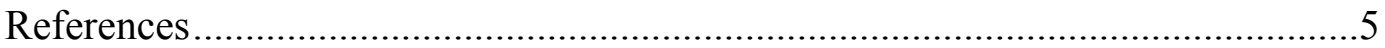

2. A COMPARATIVE STUDY OF CONCURRENT ACOUSTIC AND DIVER SURVEY DATA IN A SHALLOW WATER CORAL REEF ECOSYSTEM .................9

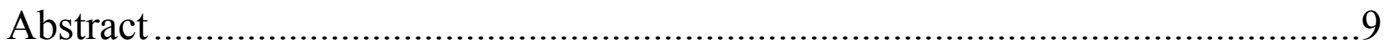

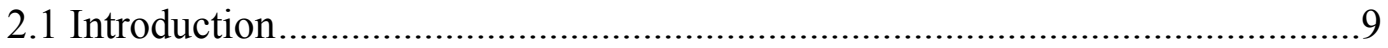

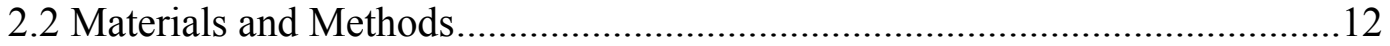

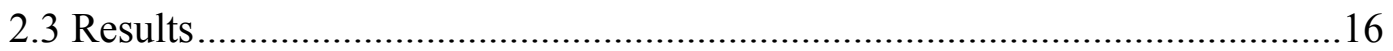

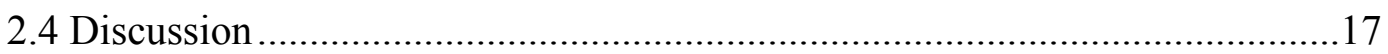

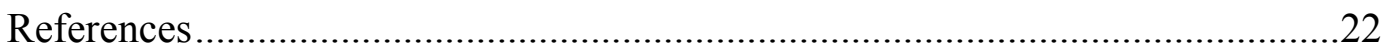

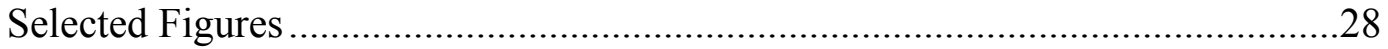

2. COMPOSITION, ABUNDANCE, AND DISTRIBUTIONS OF FISH COMMUNITIES ASSOCIATED WITH A HIGH LATITUDE CORAL REEF,

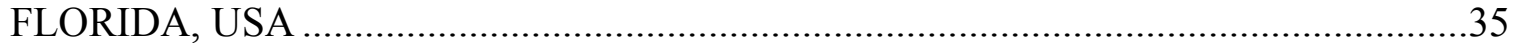

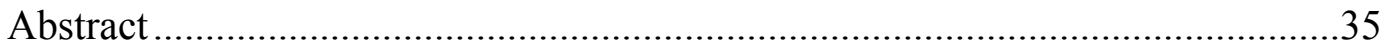

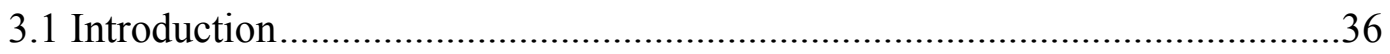

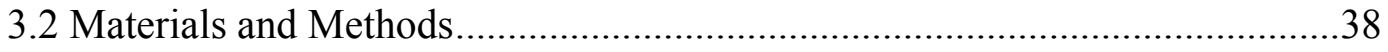

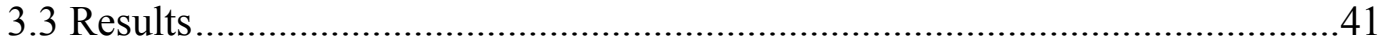

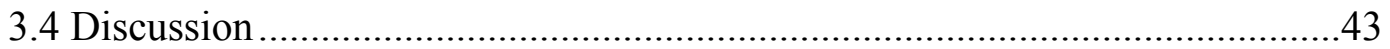

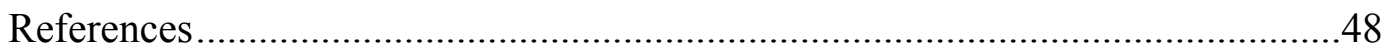

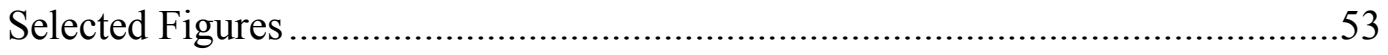

4. CONCLUSIONS, IMPLICATIONS, AND FUTURE DIRECTIONS ......................66

Conclusions, implications, and future directions ...............................................66

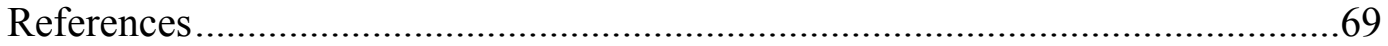




\section{LIST OF TABLES}

TABLE

PAGE

1. Results of generalized linear models using reef characteristics to predict estimates of density by both acoustic and diver methodologies. Significance was set at $\alpha=0.05$ for all tests.

2. Percent biomass contributions between families observed in diver-based surveys. Biomass was estimated using standard length-weight relationships, and a total of 23 families were recorded.

3. Family contributions to biomass compared between seasons. Highlighted is the only noticeable difference being the replacement of the Carangids (Jacks) with the family Labridae (Wrasses) in the dry season.

4. Percent Biomass contributions between strata, with those species considered apex predators highlighted in gray.

5. Results of a two way crossed Bray-Curtis similarity percentage routine (SIMPER) showing the major contributors to differences between strata and season. These top 8 species contribute to over $50 \%$ of the differences in community composition at a site....61

6. Comparison of percent biomass contributions by species in northern Miami-Dade County and a remote reef on the Flower Gardens, TX. Highlighted in gray are species considered to be apex predators. 


\section{LIST OF FIGURES}

FIGURE

PAGE

1. Range of survey strata in southeastern Florida. Individual strata contained 18 transects, 6 of which were randomly chosen on a given survey day. Benthic reef maps courtesy of SEFCRI (2011).

2. Representative $38 \mathrm{kHz}$ echogram of acoustic analysis showing many single targets across the third reef tract crest.

3. Fish density derived from both diver and acoustic surveys across all reef tracts.

4. Linear regression of fish density estimates described by acoustic and diver surveys ...31

5. Comparison of fish length estimations between diver and acoustic surveys. Lengths between survey methods are different, however each shows an increase in average fish size between seasons.

6. Linear regression of diver density estimates and acoustic density estimates show a significant positive correlation.

7. Region of Northern Miami-Dade County surveyed during the study. In the right hand panel, the three contiguous reef tracts run parallel to shore, north to south.

8. Differences between the wet and dry season in acoustically estimated biomass (top), fish length as approximated by acoustic TS (bottom). Bars represent standard error. .....54

9. Acoustic estimates of biomass, $\mathrm{s}_{\mathrm{v}}$, across reef tracts. Bars represent standard error. ...55

10. Acoustic estimates of biomass, $\mathrm{s}_{\mathrm{v}}$, in both the dry (gray bars) and wet season (black bars). Differences between reef tract within each season were significant, however only the first reef showed significantly higher biomass estimates between season on the same reef tract. Bars represent standard error.

11. Principle Components Ordination on the results of a Bray-Curtis Similarity matrix based on species abundance by survey site. A significant clumping of South strata (3) sites apart from other strata is evidenced, as well as a less clear but significant distinction between seasonal composition.

12. Percent biomass contributions to reef tract of the top three SIMPER analysis species: H. flavolineatum (A), A. bahianus (B), and B. capriscus (C).

13. Species richness across latitudes encompassed in the survey area show an increase in species richness with a decrease in latitude $\left(\mathrm{R}^{2}=0.1907, \mathrm{P}<0.05\right)$. 
14. Average fish densities recorded during diver-based surveys around the world. Plotted data include Orpheus Island, Great Barrier Reef (Ackerman and Bellwood, 2000), the Flower Gardens, Texas (NOAA, 2014), the Florida Keys (Burkepile et al., unpublished data), the northwest Hawaiian Islands (NWHI, Parrish et al., 2004), Broward County (Ettinger et al., 2001), and northern Miami in the wet and dry seasons. Bars represent standard error 


\section{CHAPTER 1 - INTRODUCTION}

\subsection{Coral reefs worldwide and in southeastern Florida}

Coral reefs are known for their high species diversity, with reef systems being second only to rainforests in terms of species per unit area (Moberg and Folk, 1999). It is estimated that while coral reefs only cover $0.1-0.5 \%$ of the ocean floor, they are home to almost a third of worldwide marine fish species (Copper, 1994; Spalding and Grenfell, 1997). This high diversity is the result of high productivity in otherwise nutrient poor geographical locations, life history, and intermediate disturbances to reef systems (Smith and Kinsey, 1976; Sale, 1977). Maturing corals create their own substrate, and the resulting benthic structural complexity has become requisite habitat for the survival of the larvae and young of important fish species (Crossland et al., 1990; Nalgerken et al., 2000; Adams et al., 2006).

Not only ecologically important, studies describing the economic importance of coral reefs estimate that reef ecosystems provide billions of dollars to local economies worldwide every year (Cesar et al., 2003). In the state of Florida alone, it is estimated that the industry based on coral reefs in Broward, Miami-Dade, Monroe, and Palm Beach counties contribute $\$ 6.3$ billion in income every year (FL DEP, 2012). These economic contributions are largely derived from recreational and commercial fisheries industries, along with ecotourism in the form of diving and snorkeling. Increasing human utilization of coastal habitats often brings associated anthropogenic pressures including unsustainable fishing, sedimentation, and the introduction of pollutants including limiting 
nutrients (Jackson et al., 2001; Lapointe et al., 2004; Ault et al., 2005; Fong and Paul, 2005).

These pressures have led to worldwide coral declines, particularly in the Caribbean region, which in some areas has been reduced to $10 \%$ or less of historic coral cover (Gardner et al., 2003). South Florida, USA, is home to the third largest barrier reef in the world that consist in the north of a series of Holocene relict ridge reefs classified as a function of distance to shore. With increasing distance these reefs are classified as ridge complex, inner, middle, and outer linear reef (Banks et al., 2007). A substantial portion of these reefs run parallel to the coastline of Miami-Dade County, whose population of 2.6 million people participated in over 18 million recreational fishing trips in 2013 (FWC, 2013). As anthropogenic influences on reef tracts increase, studies in the region have investigated pressures responsible for the decline of coral health, abundance, and species distributions (Moyer et al., 2003; Banks et al., 2008; Lirmen et al., 2011).

Despite the knowledge that decreased coral coverage results in a concomitant decrease in fish community health, few peer-reviewed studies concern the fish assemblages utilizing these reefs as habitat (Jones et al., 2004; Cheal et al., 2008). Primarily ignored in the literature, descriptions of northern Miami-Dade County fish communities by fisheries independent studies are limited to assessments of artificial reef health (Jordan, 2005; Thanner et al., 2006; Walker et al., 2009; Ault and Franklin, 2011; Gregg, 2013).

\subsection{Review of reef survey methodology}

Our understanding of reef community dynamics and biomass distributions is primarily obtained through diver-based visual surveys. Such surveys provide detailed 
insight into variation in species compositions, length distributions, and abiotic/biotic reef characteristics, but are subject to inherent biases that limit our ability to infer conclusions reef health (Samoilys and Carlos, 2000; Harvey et al., 2002; Carr et al., 2013; Irigoyen et al., 2013). It is known that atypical behavior exhibited in the presence of divers can result in over or underestimation of fish densities, and bias conclusions of community dynamics (Watson et al., 1995; Dickens et al., 2011). Examinations of data collected in the presence and absence of divers note a decrease in fish biomass with divers present, and recommend complementary methods to account for declines in local biomass as a result of diver presence (Stanley and Wilson, 1995; Schmidt and Gassner, 2006).

Acoustic methods, though traditionally applied to deep, species poor habitats offer a rapid and non-invasive method to collect spatially explicit high-resolution biological data (Simmonds and MacLennan, 2005). Preventing widespread use in shallow environments such as a coral reef ecosystem, are limitations including an potentially noisy environment characterized by high levels of reverberation and an acoustic "dead zone, in which an echosounder may not be able to distinguish an individual target from complex benthic structure (Fabi and Sala, 2002; Simmonds and MacLennan, 2006). Despite challenges in applications, several studies have shown promise in utilizing acoustic methods to increase areal coverage of surveys on a coral reef (Taylor et al., 2006; Colin, 2012). These studies do not attempt to make the results of acoustic and diver surveys directly comparable, but rather, compare the results of the surveys on independent scales. This suggests that combined survey methods with an emphasis on using diver surveys as an acoustic ground truth could ease the logistical constraints of using divers to describe large areas of reef (Guillard and Verges, 2007). 


\subsection{Conclusion}

Despite economic and ecological importance, our ability to survey coral reefs still requires improvement. Here I present the opportunity to address a unique methodological issue, while beginning to provide information on important reef communities in northern Miami-Dade County. I hypothesized that by creating a comparable metric of fish density between disparate survey methods, I would be able to examine our ability to complementarily combine non-invasive survey methods. I further hypothesized that reef communities would change as a function of season, as well as with proximity to regions of mixing with anthropogenically influenced waters. Finally, I planned to use the results of diver surveys to examine patterns in fish species distributions across individual reef tracts in the county, and across season. 


\section{References}

Adams, A.J., Dahlgren, C.P., Kellison, G.T., Kendall, M.S., Layman, C.A., Ley, J.A, Nagelkerken, I., and Serafy, J.E. (2006) Nursery function of tropical back-reef systems. Marine Ecology Progress Series 318: 287-301

Ault, J.S., Smith, S.G., and Bohnsack, J.A. (2005) Evaluation of average length as an estimator of exploitation-n status for the Florida coral-reef fish community. ICES Journal of Marine Science 62: 417-423

Ault, J.S., and Franklin, E.C. (2011) Fisheries Resource Status and Management Alternatives for the Southeast Florida Region. Report to Florida DEP. Miami Beach, FL. Pp 105

Banks, K.W., Riegl, B.M., Richards, V.P., Walker, B.K., Helmle, K.P., Jordan, L.K.B., Phipps, J., Shivji, M.S., Spieler, R.E., and Dodge, R.E. (2008) The Reef Tract of Continental Southeast Florida (Miami-Dade, Broward and Palm Beach Counties, USA). Coral Reefs of the USA, Springer Science+Business Media: 175- 219

Carr, M.H., Malone, D.P., Hixon, M.A., Holbrook, S.J, Schmitt, R.J. (2013) How Scuba Changed Our Understanding of Nature: Underwater Breakthroughs in Reef Fish Ecology. Research and Discoveries: 157

Cesar, H., Burkeand, L., and Pet-Soede, L. (2003) The economics of worldwide coral reef degradation. Cesar Environmental Economics Consulting, Arnhem, and WWFNetherlands, Zeist, The Netherlands: 23 pp.

Cheal, A.J., Wilson, S.K., Emslie, M.J., Dolman, A.M., and Sweatman, H. (2008) Responses of reef fish communities to coral declines on the Great Barrier Reef. Marine Ecology Progress Series 372: 211-223

Colin, P. L. (2012). Studying and monitoring aggregating species. In Reef fish spawning aggregations: biology, research and management (pp. 285-329). Springer Netherlands.

Copper, P. (1994) Ancient reef ecosystem expansion and collapse. Coral Reefs 13: 3-11

Crossland, C.J., Hatcher, B.G., and Smith, S.V. (1991) Role of coral reefs in global ocean production. Coral Reefs 10: 55-64

Fabi, G., and Sala, A. (2002) An assessment of biomass and diel activity of fish at an artificial reef (Adriatic Sea) using a stationary hydroacoustic technicque. ICES Journal of Marine Science 59: 411-420 
Florida Department of Environmental Protection (2012) Florida's Coral Reef Protection Act, Brochure.

Florida Fish and Wildlife Commission (2013). Annual fisheries data report, myfwc.com.

Fong, P., and Paul, V.J. (2011) Coral Reefs: An Ecosystem in Transition, Springer Science+Business Media: 341-272

Gardner, T.A., Cote, I.M., Gill, J.A., Grant, A., and Watkinson, A.R. (2003) Long-term region-wide declines in Caribbean corals. Science 301: 958-960

Gregg, K. (2013) Management Considerations for the Southeast Florida Coral Reef Ecosystem. Report to the National Oceanic and Atmospheric Administration, Coral Reef Conservation Program and the National Marine Fisheries Service. West Palm Beach, FL. $\operatorname{Pp} 42$

Guillard, J., and Verges, C. (2007) The Repeatability of Fish Biomass and Size Distribution Estimates Obtained by Hydroacoustic Surveys Using Various Sampling Strategies and Statistical Analyses. International Review of Hydrobiology 92 (6): 605617

Harvey, E., Fletcher, D., and Shortis, M. (2002) Estimation of reef fish length by divers and stereo-video: A first comparison of the accuracy and precision in the field on living fish under operational conditions. Fisheries Research 57: 255-265

Irigoyen, A.J., Galvan, D.E., Venerus, L.A., and Parma, A.M. (2013) Variability in Abundance of Temperate Reef Fishes Estimated by Visual Census. PLOS One 8: e61072 Watson, R.A., Carlos, G.M., and Samoilys, M.A. (1995) Bias introduced by the nonrandom movement of fish in visual transect surveys. Ecological Modelling 77: 205-214

Jackson, B.C., Kirby, M.X., Berger, W.H., Bjorndal, K.A., Botsford, L.W., Bourque, B.J., Bradbury, R.H., Cooke, R., Erlandson, J., Estes, J.A., Hughes, T.P., Kidwell, S., Lange, C.B., Lenihan, H.S., Pandolfi, J.M., Peterson, C.H., Steneck, R.S., Tegner, M.J., and Warner, R.R. (2001) Historical Overfishing and the Recent Collapse of Coastal Ecosystems. Science 293: 629-639

Jones, G.P., McCormick, M.I., Srinivasan, M., and Eagle, J.V. (2004) Coral decline threatens fish biodiversity in marine reserves. PNAS 101: 8251-8253

Jordan, L.K.B., Gilliam, D.S., and Spieler, R.E. (2005) Reef fish assemblage structure affected by small-scale spacing and size variations of artificial patch reefs Journal of Experimental Marine Biology and Ecology 326: 170-186 
Lirman, D., Schopmeyer, S., Manzello, D., Gramer, L.J., Precht, W.F., Muller-Karger, F., Banks, K., Barnes, B., Bartels, E., Bourque, A., Byrne, J., Donahue, S., Duquesnel, J., Fisher, L., Gilliam, D., Hendee, J., Johnson, M., Maxwell, K., McDevitt, E., Monty, J., Rueda, D., Ruzicka, R., Thanner, S. (2011) Severe 2010 Cold-Water Event Caused Unprecedented Mortality to Corals of the Florida Reef Tract and Reversed Previous Survivorship Patters. PLOS One 6: 1-10

Moberg, F., and Folke, C. (1999) Ecological goods and services of coral reef ecosystems. Ecological Economics 29: 215-233

Moyer, R.P., Riegl, B., Banks, K., and Dodge, R.E. (2003) Spatial patterns and ecology of benthic communities on a high-latitude South Florida (Broward County, USA) reef system. Coral Reefs 22: 447-464

Nagelkerken, I., van der Velde, G., Gorissen, M.W., Meijer, G.J., van’t Hof, T., and den Hartog, C. (2000) Importance of Mangroves, Seagrass Beds and the Shallow Coral Reef as a Nursery for Important Coral Reef Fishes, Using a Visual Census Technique.

Estuarine, Coastal and Shelf Science 51: 31-44

Samoilys, M., and Carlos, G. (2000) Determining Methods of Underwater Visual Census for Estimating the Abundance of Coral Reef Fishes. Environmental Biology of Fishes 57: 289-304

Sale, P.F. (1977) Maintenance of High Diversity in Coral Reef Fish Communities. The American Naturalist 111: 337-359

Schmidt, M.B., and Gassner, H. (2006) Influence of scuba divers on the avoidance reaction of a dense vendace (Coregonus albula $L$.) population monitored by hydroacoustics. Fisheries Research 82: 131-139

Simmonds, E.J., and MacLennan, D.N. (2005) Fisheries Acoustics: Theory and Practice, $2^{\text {nd }}$ edn. Blackwell Science, Oxford

Smith, S.V., and Kinsey, D.W. (1976) Calcium Carbonate Production, Coral Reef Growth, and Sea Level Change. Science 194: 937-939

Spalding, M.D., and Grenfell, A.M. (1997) New estimates of global and regional coral reef areas. Coral Reefs 16: 225-230

Taylor, J.C., Eggleston, D.B., and Rand, P.S. (2006) Nassau grouper (Epinephelus striatus) spawning aggregations: hydroacoustic surveys and geostatistical analysis. NMFS Professional Paper: 18-25 
Thanner, S.E., McIntosh, T.L., and Blair, S.M. (2006) Development of benthic and fish assemblages on artificial reef materials compared to adjacent natural reef assemblages in Miami-Dade County, Florida. Bulletin of Marine Science 78(1): 57-70

Walker, B.K., Jordan, L.K.B., and Spieler, R.E. (2009) Relationship of Reef Fish Assemblages and Topographic Complexity on Southeastern Florida Coral Reef Habitats. Journal of Coastal Research 53: 39-48 


\title{
CHAPTER 2 - A COMPARATIVE STUDY OF CONCURRENT ACOUSTIC AND DIVER SURVEY DATA IN A SHALLOW WATER CORAL REEF ECOSYSTEM
}

\author{
Abstract \\ Data on coral reef fish communities collected by diver-based surveys are subject to \\ inherent biases which have the potential to limit holistic, spatially expansive \\ investigations of reef communities. Though studies show worldwide declines in coral \\ health and density, it is possible that evidence of decline on limited spatial scales may be \\ masking reef-wide patterns. It is clear that new methods are necessary to investigate reef \\ communities on wider spatial scales than in some studies previously reporting habitat \\ declines. In this paper we compare and contrast fish density estimates as derived by \\ traditional diver surveys and concurrent acoustic surveys. Fish densities derived from \\ both diver and acoustic surveys display congruent patterns across independent parallel \\ reef tracts. In further agreement, estimates of fish lengths directly observed by divers and \\ estimated acoustically suggest that a seasonal increase in size exists across the surveyed \\ reefs. The efficacy of diver-based surveys was shown to decline with increasing \\ visibility, while acoustic survey results remained insensitive to changes in visibility. \\ Consistent results between survey methods suggest that studies may utilize combined \\ methods to investigate fish density distributions on large spatial scales not typically \\ examined.
}

\subsection{Introduction}

Coral reefs contain disproportionally high levels of species diversity, and it is estimated that while coral reefs cover merely $0.1-0.5 \%$ of the ocean floor, they are home to almost a third of worldwide marine fish species (Copper, 1994; Spalding and Grenfell, 
1997). Increasingly common anthropogenic pressures including eutrophication, sediment loading, and rising global temperatures have led to severe declines in coral reef health that are concomitant with declines in fish density (Knowlton, 2001; Hughes et al., 2003; Walther et al., 2007; Hoegh-Guldberg, 2007). It has been suggested that the alarming patterns and declines in fish and coral densities are valid only across areas explicitly surveyed by divers, and that minimal spatial resolution of current methodologies may limit our ability to extrapolate these results to larger spatial scales (Andrefouet and Riegl, 2004). Given the economic and ecological value of coral reefs and the increasing emphasis being placed on scientifically informed resource management, it is critical to complement current methods and explore new methodological approaches in an effort to minimize current biases and limitations.

Our understanding of reef community dynamics and biomass distributions is primarily obtained through diver-based visual surveys. Such surveys provide detailed insight into estimated community length distributions, species compositions, and abiotic/biotic reef characteristics (Carr et al., 2013). However, due to highly variable water clarity, limited bottom time, and logistical difficulties in surveying large areas of reef, current methods may result in exaggerated evidence of reef health decline (Samoilys and Carlos, 2000; Harvey et al., 2002; Irigoyen et al., 2013). Further, atypical behavior exhibited in the presence of divers conducting a survey can result in over or underestimation of fish densities (Watson et al., 1995; Dickens et al., 2011). In fact, examinations of data collected in the presence and absence of divers note a decrease in fish biomass with divers present, and state the need for complementary methods to 
account for declines in local biomass as a result of diver presence (Stanley and Wilson, 1995; Schmidt and Gassner, 2006).

Acoustics offer a rapid and non-invasive method to collect spatially explicit highresolution biological data across large areas. However, acoustic methods have traditionally been applied to deep, species poor habitats due to several logistical and technical considerations (Simmonds and MacLennan, 2005). One such consideration is the acoustic "dead zone, in which an echosounder may not be able to distinguish an individual target from complex benthic structure (Fabi and Sala, 2002; Simmonds and MacLennan, 2006). Further, using acoustic data to partition single targets to a relevant taxonomic level is primarily achieved through knowledge of unique scattering properties coupled with target behavior, followed by direct collections for ground-truthing (Emmrich et al., 2010). Effective in environments with few species, these methods of identification can be confounded by the abundance and diversity of coral reefs (Green et al., 1996; Mumby et al., 1997). Despite difficulties, Taylor et al (2006) were successful in their attempts to utilize acoustic estimates to elucidate the numbers of spawning Nassau grouper by conducting a series of concurrent ground-truthing diver surveys. Similar studies without accompanying diver surveys have led to potentially "suspect" conclusions in estimates of population sizes (Ehrhardt and Deleveaux, 2007; Colin, 2011). Moreover, these studies do not attempt to make the results of acoustic and diver surveys directly comparable, but rather, compare the results of the surveys on independent scales. To explore comparisons on similar scales, it may be useful to further examine one of the primary outputs of acoustic data, $s_{a}$, or the amount of echo energy scattered back to a transducer over a sampled area and depth. $\mathrm{s}_{\mathrm{a}}$ can be quickly and easily 
converted into an estimate of fish density $\left(\right.$ fish $\mathrm{m}^{-2}$ ) that may be comparable to the results of a diver survey (MacLennan et al., 2002). Combined survey methods with an emphasis on using diver surveys as an acoustic ground truth could ease the logistical constraints of using divers to describe large areas of reef, while offering to acoustic results the same confidence afforded to traditional surveys (Guillard and Verges, 2007).

In this paper, we compare the results of a series of concurrent observations utilizing both traditional diver-based and acoustic survey methods in a coastal coral reef ecosystem. Specifically, our objective was to create a comparable metric of fish density from each method to examine effects of reef characters such as live coral cover and depth. Density differences as a function of reef tract and proximity to sources of estuarine mixing were also investigated. We then determine if fish densities derived from either method exhibit similar distributional patterns. Evidence of similar patterns between density estimates from both survey methods could allow for confidence in expanding the spatial coverage of a minimal number of diver surveys by utilizing acoustic methods.

\subsection{Methods and Materials}

Study site

The study area ranges from approximately $6 \mathrm{~km}$ south of Pt. Everglades in Ft. Lauderdale $\left(26.03312^{\circ},-80.072672^{\circ}\right)$ at the very southern portion of Broward county, to $3 \mathrm{~km}$ north of Government Cut, near South Miami Beach $\left(25.779022^{\circ},-80.062706^{\circ}\right)$ (Figure 1). A series of Holocene relict reefs in this region are typically classified as a function of distance to shore. Heading towards open ocean, reef types include ridge complex, inner, middle, and outer linear reef (Sathe et al., 2008) For the purposes of this 
study only the three reef tracts classified as "linear" (Figure 1) were surveyed, as structural similarities allowed for the most direct observations of community changes.

We developed a random stratified sampling design with each of three strata (North, Haulover Inlet, and South) being divided into 6 substrata. In each substrata, three evenly spaced transect lines running perpendicular to linear reef tracts were created (Figure 1). During each sampling event, a single transect line was randomly selected within each sub-strata, yielding six total transects surveyed per strata, per survey day. Survey days were selected based on wave heights below 1 meter to allow for highest quality acoustic data. To complement acoustic surveys, during each day, two of the six acoustic transects were randomly selected and were subject to diver-based surveys. To control for temporal variation, all diver-based surveys and acoustic transects were conducted on the same day, with at least 30 minutes between each method to normalize fish behavior. Surveys ran from August of 2013 through March, 2014 with each strata surveyed twice per month, for a total of 42 acoustic transects complemented by divers. Reef Visual Census

Divers were deployed in teams of two onto transect sites located in the center of each linear reef tract. Diver teams carried a dive flag equipped with a handheld Garmin GPS unit to provide diver position for post-processing. Data collection was based on a modified reef visual census in which divers recorded fish species, estimated length, abundance, and characteristics of interest (e.g. Live coral cover, depth, visibility, etc) (Smith et al., 2011). To minimize diver collection bias, all divers participated in quizzes on reef fish identification and length estimation prior to any survey action following (SEFCRI, 2012). Measures of abundance at each site were converted to a standard 
density metric (fish $\mathrm{m}^{-2}$ ) before analysis. To make diver surveys more comparable to their acoustic counterparts, small and cryptic benthic species that would not be easily detected by acoustic methods and were not of primary management concerns (i.e. Yellowhead wrasses, Bluehead wrasses, Damselfish sp., etc.) were eliminated in post-processing. Acoustic Surveys

Acoustic data were collected using a calibrated SIMRAD EK60 multi-frequency echosounder system operating a 38 and $120 \mathrm{kHz}$ split-beam transducer interfaced to a laptop computer running current ER60 software (SIMRAD, v2.0). Vessel position was recorded using a WASS-enabled USB Garmin GPS unit that was corrected for positional offsets from the face of the transducer. Transducers were mounted to the survey vessel by an articulated mounting pole allowing for easy deployment into a downward facing position, and were calibrated by the standard sphere method prior to surveys (Foote et al., 1987). The survey vessel was driven at an average speed of $2 \mathrm{~m} \mathrm{~s}^{-1}$ east to west across all three linear reefs on a randomly selected sub-strata transect.

Acoustic data were manually inspected and post-processed in Echoview 6.1 (Sonar Data Pty., Ltd.). An analysis threshold was applied to the volume backscattering (Sv) data in addition to a bottom detection algorithm to remove extraneous acoustic backscatter (eg. benthic habitat, air bubbles, and organic waste). Additional manual inspections removed any remaining undesired data and the echograms were binned into $2.5 \mathrm{~m}$ horizontal by $2.5 \mathrm{~m}$ depth analysis cells. Visibility as determined by divers was used as a "ceiling", establishing the analysis cells over a reef to eliminate upper water column information not available to diver surveys (Figure 2). Finally, schooling events on these reefs were detected very rarely in both survey methods, and were excluded as outliers in 
the analysis. Acoustic fish density estimates were calculated by using the backscattering cross-section $\left(\sigma_{\mathrm{bs}}\right)$ and average target strength $(\mathrm{TS})$ values $\left[\mathrm{TS}=10 \log _{10} \sigma_{\mathrm{bs}}\right]$ of single targets detected on a reef site (Eq.1). The area backscattering coefficient, $\mathrm{s}_{\mathrm{a}}\left[\mathrm{s}_{\mathrm{a}}=\int_{z 1}^{z 2} \mathrm{~Sv} *\right.$ $\mathrm{dz}$, was then used to calculate fish densities (fish $\mathrm{m}^{-2}$ ) over a reef as described in MacLennan et al., 2002 (Eq.2).

$$
\begin{aligned}
& \sigma_{\mathrm{bs}}=10^{\wedge}(\mathrm{TS} / 10) \\
& \text { Fish } \mathrm{m}^{-2}=\mathrm{s}_{\mathrm{a}} / \sigma_{\mathrm{bs}}
\end{aligned}
$$

Finally, fish lengths as estimated by acoustics were derived by using the average TS values of single targets identified in processed echograms following (Love, 1977). Density Analysis

Fish density derived from both acoustic and diver-based methods were converted to their root form to normalize residuals and meet the assumptions of a Generalized Linear Model (GLM). A GLM using type III sums of squares was then used to test significance of the effects of measured variables including depth, reef tract, strata, visibility, and live coral cover on fish densities. The most parsimonious model was obtained through a stepwise removal of variables not found to be significant in explaining variance. All variables in the lowest AIC model shown to be significant in explaining variance were then analyzed individually for significance using an analysis of variance (ANOVA). Pairwise comparisons were performed with Tukey's post hoc tests, estimates are reported as mean and standard error (mean \pm s.e). Analyses were performed in the statistical programming environment R 3.1.1 (R Development Core Team, 2014). As residuals of length estimates from both survey type did not approximate a normal distribution under any transformation, A Mann-Whitney rank sum test was used to 
examine differences between length estimations by both divers and acoustics in SigmaPlot version 12.5 (Systat Software, Inc). Finally, a linear regression on diver and acoustic density estimates was conducted to investigate possible correlations between density estimates.

\subsection{Results}

Two unique models were created, one each for diver densities and acoustic densities, and both show evidence of similar fish density patterns. Both methods agree that linear reef tract was a significant predictor of fish density (Diver: $\mathrm{P}=0.038, \mathrm{n}=38$; Acoustic $\mathrm{P}=0.0193, \mathrm{n}=38$; Table 1 ). Mean fish density across reef tracts increased with distance from shore in both acoustic and diver surveys. Acoustically derived fish densities increased by an order of magnitude between the first and second reef tract, with a smaller increase of 0.005 fish $\mathrm{m}^{-2}$ between the second and third reef tract (Figure 3). Acoustic estimates of density were quite small in comparison to their diver derived counterparts, although diver densities illustrate a similar pattern of density increasing with distance from shore. Diver estimates show a two-fold increase between the first and second reef tract, and a three-fold increase in density from the first to the third reef tract (Figure 3).

Visibility in the water significantly explained variance in the model within diver surveys, where increasing visibility led to decreased diver density estimates $\left(n=38, r^{2}=\right.$ $0.1424, \mathrm{P}=0.0203)$, while acoustic estimates remained unaffected $\left(\mathrm{n}=38, \mathrm{r}^{2}=0.0055, \mathrm{P}\right.$ $=0.520)$ (Figure 4). The remainder of factors thought to have potential in predicting densities did not have any effect on acoustic or diver density estimates (Table 1). 
Although not a significant predictor of fish density, average depth of each reef tract was found to be different. The first reef tract was shallowest $(10.07 \pm 1.50 \mathrm{~m})$, followed by similar depths of the second $(15.28 \pm 2.11 \mathrm{~m})$ and third reef tract $(16.39 \pm$ $1.29 \mathrm{~m}$ ). Fish length estimations as derived by acoustic TS varied significantly between the wet and dry season with an average length of $19.8( \pm 1.7)$, and $24.8( \pm 1.3) \mathrm{cm}$ respectively (Figure 5, P $<0.001, \mathrm{n}=242$ ). Diver estimates of length showed a similar significant trend, with average length of acoustically detectable fishes ranging from 11.3 $\mathrm{cm}( \pm 0.3)$ in the wet season, to $14.8 \mathrm{~cm}( \pm 0.3)$ in the dry season (Figure $5, \mathrm{P}<0.001, \mathrm{n}=$ 1322). A significant positive correlation between density estimates from both methods was found across all strata and reef tracts (Figure 6, $\mathrm{P}<0.001, \mathrm{R}^{2}=0.336$ ).

\subsection{Discussion}

Discussion

Although studies seeking to improve the ability to investigate coral reef habitats are common, we believe this is the first account of direct comparisons of coincident diver and acoustic surveys on reef ecosystems with the goal of deriving a comparable metric of fish density (Fowler, 1987; Lowry et al., 2012; Mallet and Pelletier, 2014). It is therefore encouraging to note that a significant positive correlation was identified between the density estimates of both methodologies, suggesting agreement of survey results between both acoustic and diver surveys. Congruent length estimations further support methodological agreement between survey approaches, detecting a significant increase in fish length between the wet and dry season. Each approach similarly gives evidence for increasing biomass on coastal reefs with increasing distance from shore, despite differences in magnitude. Notably, our results indicate that diver surveys were greatly 
influenced by visibility, while acoustic results remained insensitive to water clarity fluctuations.

It has been previously documented that increased water clarity enhances fish avoidance and attraction behavior, influencing the sizes and species of fish likely to be encountered on a survey (Bozec et al., 2011). In particular, larger fish are less likely to approach divers on high visibility days, precluding precise estimations of community biomass and preventing accurate representation of species abundance in a site (Bernard et al., 2013). Given that lengths as estimated by acoustic surveys detected larger fish on average than diver-based surveys, it seems possible that complementary acoustic surveys may ameliorate this bias.

Density estimates obtained by both divers and acoustics show similar distributional patterns, however, differences in magnitude and lower overall estimations of density by acoustics were noted. A possible explanation for these differences may be found as an artifact of our survey design, rather than a limitation of acoustic technology. Diver reef visual censuses were stationary on a reef for fifteen minutes, while the acoustic survey vessel made a single pass over a reef that may have only lasted between one and three minutes. Differences in survey effort such as this have been shown to affect abundance estimates of fish observed by a diver, and attempts to mimic a diver-based survey using an ROV have shown similar results can be attained by using equal effort between methodologies (Girolamo and Mazzoldi, 2001; Parry et al., 2002; Patterson et al., 2008). Though not always the case, disparate collection methods with similar spatial coverage (eg. acoustics and trawling) show a general agreement in estimates of biomass (Leujak and Ormond, 2007; Emmich et al., 2012; Yule et al., 2013). A methodological 
adjustment in the future to transect based diver surveys may standardize effort on each reef to further enhance comparability between results of each survey.

Both methods identified that the third reef tract contains significantly higher fish densities, indicating that the third reef is an important habitat for fish biomass in the region. This higher density on the third reef may be attributed to the increased structural complexity on this reef tract in comparison to the first two linear reefs. Although the third reef tract is the narrowest of the linear reefs, a steep rise on the inshore and offshore edge presents the opportunity for complex microhabitat that may be nonexistent on the flatter inner reefs. These increases in structural complexity have elsewhere been shown to have positive effects on fish densities and overall biomass in comparison to reefs with less rugosity (Beukers and Jones, 1998; Almany, Jones and Syms, 1998; Graham and Nash, 2013). The third reef tract is also deeper than the first reef and though similar in depth to the second reef, was more structurally complex. Depth did not have a significant effect on density estimates, however, it may still act as a depth refuge for fish communities (Tyler et al., 2009).

In our efforts to enhance the comparability of acoustic surveys, we omitted both upper water column data that would not be visible to divers, as well as the rare occurrences of schooling events. By making such accommodations we have obtained comparable results between diver-based and acoustic data that show similar patterns in fish density distributions. It is recommended that in the future, schooling events are not eliminated from data. These schools are a natural reef occurrence and their contributions to fish density on a reef should not be discounted in the interest of directly comparable data, especially in regions where schools are more prevalent than our study area. 
The acoustic dead zone near benthic structure presents difficulties in examining benthic microstructure, and in the interest of a comparable density estimate benthic species not of immediate commercial interest were eliminated from our diver data. By eliminating benthic species from our comparisons we preclude the majority of coral associated reef fishes that may benefit from increased coverage (Bell and Galzin, 1984; Wilson et al., 2010). Thus it is unsurprising that our data from both divers and acoustic surveys show no significant correlation between coral cover and fish density. Even without benthic species removal, we believe that the comparatively sparse distributions of live coral in southeastern Florida have a reduced effect on fish densities (Gilliam, 2012). It is possible that on these reefs structural complexity is more important than coral density, as increasing complexity often means that fish utilize reef microhabitats (e.g. Channels, crevices, etc) (Connell and Jones, 1991; Hixon and Beets, 1993; Gratwicke and Speight, 2005). Future studies that may be interested in more closely exploring benthic species and their relationship to coral cover should retain them in analysis of diver collected data to supplement acoustic results.

Strata in this study were demarcated as a function of distance to Haulover Inlet, one of several south Florida inlets which link the intra-coastal canal and Biscayne Bay to the ocean. These inlets allow a mixing of anthropogenically polluted waters with the near-shore habitat, and studies in the region correlate the increasing frequency of macroalgal blooms directly to these sources of limiting nutrients (Lapointe et al., 2004; Barile, 2004; Lapointe et al., 2005). Declines in live coral cover typically associated with algal blooms should cause a concurrent decline in fish density, however, evidence of increased primary productivity may lead to an increase in fish biomass endemic to 
enriched sites (Pandolfi et al., 2003; Jones et al., 2004; Bruno and Selig, 2007). Although there was evidence of increased fish density near Haulover Inlet, it was not significant in our data in either survey method. It is possible that proximity to Government Cut in the south, and Port Everglades in the north may be homogenizing the effects of anthropogenic runoff on the reefs. Further study is warranted to examine the exact effects of this estuarine mixing on near-shore reefs.

In this paper we examined the distribution and densities of reef fish communities as surveyed by disparate methodologies. Future studies utilizing this combination of survey methods should further attempt to harmonize methods, while not sacrificing useable information. We recommend substituting our cylindrical reef visual census with a diver transect survey method, as it more closely aligns with data collected by acoustic surveys. We would further recommend an increase in reef coverage by the acoustic survey vessel as a single transect perpendicular across a reef may result in erroneous estimates of density. Results of both survey method show congruent patterns in fish density, save for previously known visual biases of the diver survey. Our attempts to compare among survey type by converting the results of acoustic surveys into a relative density metric appear to have shown promise in increasing the spatial coverage of important reef surveys. It is our hope that future combined survey methodologies will, by lowering requisite diver efforts necessary to survey a region, ameliorate logistical constraints inherent in surveys attempting to describe reef communities, and that increased spatial coverage will provide a more synoptic view of reef health. 


\section{References}

Almany, G.R. (2004) Does increased habitat complexity reduce predation and competition in coral reef fish assemblages? Oikos 106 (2): 275-284

Anderson, W.T., Paul, V.J., and Sneed, J.M. (2012) Using Cyanobacteria and Macroalgae Stable Isotopes as Anthropogenic Point and Non-Point Source Nutrient Indicators. Final Report for Southeast Florida Coral Reef Initiative Land Based Sources of Pollution Local Action Strategy Project 32.

Andrefouet, S., and Riegl, B. (2004) Remote sensing: a key tool for interdisciplinary assessment of coral reef processes. Coral Reefs 23: 1-4

Barile, P.J. (2004) Evidence of Anthropogenic Nitrogen Enrichment of the Littoral Waters of East Central Florida. Journal of Coastal Research 20: 1237-1245

Bernard, A.T.F., Gotz, A., Kerwath, S.E., and Wilke, C.G. (2013) Observer bias and detection probability in underwater visual census of fish assemblages measured with independent double-observers. Journal of Experimental Marine Biology and Ecology 443: $75-84$

Beukers, Joanne S., and Geoffrey P. Jones. "Habitat complexity modifies the impact of piscivores on a coral reef fish population." Oecologia 114.1 (1998): 50-59

Bell, J.D., and Galzin, R. (1984) Influence of live coral cover on coral-reef fish communities. Marine Ecology Progress Series 15: 265-274

Bozec, Y.M., Kilbicki, M., Laloe, F., Mou-Tham, G., and Gascuel, D. (2011) Factors affecting the detection distances of reef fish: implications for visual counts. Marine Biology 158 (5): 969-981

Bruno, J.F., and Selig, E.R. (2007) Regional Decline of Coral cover in the Indo-Pacific: Timing, Extent, and Subregional Comparisons. PLoS ONE 8: 1-8

Carr, M.H., Malone, D.P., Hixon, M.A., Holbrook, S.J, Schmitt, R.J. (2013) How Scuba Changed Our Understanding of Nature: Underwater Breakthroughs in Reef Fish Ecology. Research and Discoveries: 157

Colin, P. L. (2012). Studying and monitoring aggregating species. In Reef fish spawning aggregations: biology, research and management (pp. 285-329). Springer Netherlands. 
Connel, S.D., and Jones, G.P. (1991) The influence of habitat complexity on postrecruitment processes in a temperate reef fish population. Journal of Experimental Marine Biology and Ecology 151 (2): 271-294

Copper, P. (1994) Ancient reef ecosystem expansion and collapse. Coral Reefs 13: 3-11 Cotter, A.J.R. and Pilling, G.M. (2007) Landings, logbooks, and observer surveys: improving the protocols for sampling commercial fisheries. Fishi and Fisheries 8: 123152

Dickens, L.C., Goatley, C.H.R., Tanner, J.K., and Bellwood, D.R. (2011) Quantifying Relative Diver Effects in Underwater Visual Censuses. PLOS One 6: 1-8

Ehrhardt, N.M., and Deleveaux, V.K.W. (2007) The Bahamas' Nassau grouper (Epinephelus striatus) fishery - two assessment methods applied to a data-deficient coast population. Fisheries Research 87: 17-27

Emmrich, M., Hellend, I.P., Busch, S., Schiller, S., and Mehner, T. (2010) Hydroacoustic estimates of fish densities in comparison with stratified pelagic trawl sampling in two deep, coregonid-dominated lakes. Fisheries Research 105 (3): 178-186

Emmrich, M., Winfield, I.J., Guillard, J., Rustadbakken, A., Verges, C., Volta, P., Jeppesen, E., Lauridsen, T.L., Brucet, S., Holmgren, K., Argillier, C., and Mehner, T. (2012) Strong correspondence between gillnet catch per unit effort and hydroacoustically derived fish biomass in stratified lakes. Freshwater Biology 57 (12): 2436-2448

Fabi, G., and Sala, A. (2002) An assessment of biomass and diel activity of fish at an artificial reef (Adriatic Sea) using a stationary hydroacoustic technicque. ICES Journal of Marine Science 59: 411-420

Foote, K.G., Knudsen, H.P., Vestnes, G., MacLennan, D.N., and Simmonds, E.J. (1987) Calibration of acoustic instruments for fish density estimation: a practical guide. ICES Cooperative Research Report No 144.

Fowler, A.J. (1987) The development of sampling strategies for population studies of coral reef fishes. A case study. Coral Reefs 6: 49-58

Futch, J.C., Griffin, D.W., Banks, K., and Lipp, E.K. (2011) Evaluation of sewage source and fate on southeast Florida coastal reefs. Marine Pollution Bulletin 62: 2308-2316

Gilliam, D.S. (2012). Southeast Florida Coral Reef Evaluation and Monitoring Project 2011 Year 9 Final Report. Florida DEP Report \#RM085. Miami Beach, FL. Pp. 49. 
Girolamo, M. D., and Mazzoldi, C. (2001) The application of visual census on Mediterranean rocky habitats. Marine Environmental Research 51: 1-16

Graham, N.A.J., and Nash, K.L. (2013) The importance of structural complexity in coral reef ecosystems. Coral Reefs 32 (2): 315-326

Gratwicke, B., and Speight, M.R. (2005) The relationship between fish species richness, abundance and habitat complexity in a range of shallow tropical marine habitats. Journal of Fish Biology 66 (3): 650-667

Green, E.P., Mumby, P.J., Edwards, A.J., and Clark, C.D. (1996) A review of remote sensing for the assessment and management of tropical coastal resources. Coastal Management 24: 1-40

Guillard, J., and Verges, C. (2007) The Repeatability of Fish Biomass and Size Distribution Estimates Obtained by Hydroacoustic Surveys Using Various Sampling Strategies and Statistical Analyses. International Review of Hydrobiology 92 (6): 605617

Harvey, E., Fletcher, D., and Shortis, M. (2002) Estimation of reef fish length by divers and stereo-video: A first comparison of the accuracy and precision in the field on living fish under operational conditions. Fisheries Research 57: 255-265

Hixon, M.A., and Beets, J.P. (1993) Predation, Prey Refuges, and the Structure of CoralReef Fish Assemblages. Ecological Monographs 63: 77-101

Hoegh-Guldberg, O., Mumby, P.J., Hooten, A.J., Steneck, R.S., Greenfield, P., Gomez, E., Harvell, C.D., Sale, P.F., Edwards, A.J., Caldeira, K., Knowlton, N., Eakin, C.M., Igelsias-Prieto, R., Muthiga, N., Bradbury, R.H., Dubi, A., and Hatziolos, M.E. (2007) Coral Reefs Under Rapid Climate Change and Ocean Acidification. Science 318: 17371742

Hughes, T.P., Baird, A.H., Bellwood, D.R., Card, M., Connolly, S.R., Folke, C., Grosberg, R., Hoegh-Guldberg, O., Jackson, J.B.C., Kleypas, J., Lough, J.M., Marshall, P., Nystrom, M., Palumbi, S.R., Pandolfi, J.M., Rosen, B., and Roughgarden, J. (2003) Climate Change, Human Impacts, and the Resilience of Coral Reefs. Science 301: 929933

Irigoyen, A.J., Galvan, D.E., Venerus, L.A., and Parma, A.M. (2013) Variability in Adundance of Temperate Reef Fishes Estimated by Visual Census. PLOS One 8: e61072 
Jones, G.P., McCormick, M.I., Srinivasan, M., and Eagle, J.V. (2004) Coral decline threatens fish biodiversity in marine reserves. PNAS 101: 8251-8253

Knowlton, N. (2001) The future of coral reefs. Proceedings of the National Academy of Sciences 98: 5419-5425

Lapointe, B.E., Barile, P.J., and Matzie, W.R. (2004) Anthropogenic nutrient enrichment of seagrass and coral reef communities in the Lower Florida Keys: discrimination of local versus regional nitrogen sources. Journal of Experimental Marine Biology and Ecology 308: $23-58$

Lapointe, B.E., Barile, P.J., Littler, M.M., Littler, D.S., Bedford, B.J., and Gasque, C. (2005) Macroalgal blooms on southeast Florida coral reefs I. Nutrient stoichiometry of the invasive green alga Codium isthmocladum in the wider Caribbean indicates nutrient enrichment. Harmful Algae 4: 1092-1105

Leujak, W., and Ormond, R.F.G. (2007) Comparative accuracy and efficiency of six coral -community survey methods. Journal of Experimental Marine Biology and Ecology 351: $168-187$

Lowery, M., Folpp, H., Gregson, M., and Suthers, I. (2012) Comparison of baited remote underwater video (BRUV) and underwater visual census (UVC) for assessment of artificial reefs in estuaries. Journal of Experimental Marine Biology and Ecology 416417: $243-253$

Maclennan, D. N., Fernandes, P. G., \& Dalen, J. (2002). A consistent approach to definitions and symbols in fisheries acoustics. ICES Journal of Marine Science: Journal du Conseil, 59(2), 365-369.

Maliao, R.J., Turingan, R.G., and Lin, J. (2008) Phase-shift in coral reef communities in the Florida Keys National Marine Sanctuary (FKNMS), USA. Marine Biology 154: 841853

Mallet, D., and Pelletier, D. (2014) Underwater video techniques for observing coastal marine biodiversity: A review of sixty years of publications (1952-2012). Fisheries Research 154: 44-62

Mumby, P.J., Green, E.P., Edwards, A.J., and Clark, C.D. (1997) Coral reef habitat mapping: how much detail can remote sensing provide? Marine Biology 130: 193-202 
Pandolfi, J.M., Bradbury, R.H., Sala, E., Hughes, T.P., Bjorndal, K.A., Cooke, R.G., McArdle, D., McClenachan, L., Newman, M.J.H., Paredes, G., Warner, R.R., and Jackson, J.B.C. (2003) Global Trajectories of the Long-Term Decline of Coral Reef Ecosystems. Science 301: 955-958

Parry, D.M., Nickell, L.A., Kendall, M.A., Burrows, M.T., Pilgrim, D.A., and Jones, M.B. (2002) Comparison of abundance and spatial distribution of burrowing megafauna from diver and remotely operated vehicle observations. Marine Ecology Progress Series 244: 89-93

Patterson, W.F., Dance, M.A., and Addis, D.T. (2008) Development of a Remotely Operated Vehicle Based Methodology to Estimate Fish Community Structure at Artificial Reef Sites in the Northern Gulf of Mexico. Proceedings of the $61^{\text {st }}$ Gulf and Caribbean Fisheries Institute.

Samoilys, M., and Carlos, G. (2000) Determining Methods of Underwater Visual Census for Estimating the Abundance of Coral Reef Fishes. Environmental Biology of Fishes 57: 289-304

Sathe, M.P., Gilliam, D.S., Dodge, R.E., and Fisher, L.E. (2008) Patterns in southeast Florida coral reef community composition. Proceedings of the $11^{\text {th }}$ International Coral Reef Symposium, Ft. Lauderdale, Florida, 7-11 July, 2008.

Schmidt, M.B., and Gassner, H. (2006) Influence of scuba divers on the avoidance reaction of a dense vendace (Coregonus albula L.) population monitored by hydroacoustics. Fisheries Research 82: 131-139

Simmonds, E.J., and MacLennan, D.N. (2005) Fisheries Acoustics: Theory and Practice, $2^{\text {nd }}$ edn. Blackwell Science, Oxford

Smith, S.H., Ault, J.S., Bohnsack, J.A., Harper, D.E., Luo, J., and McClellan, D.B. (2011) Multispecies survey design for assessing reef-fish stocks, spatially explicit management performance, and ecosystem condition. Fisheries Research 109: 25-41

Spalding, M.D., and Grenfell, A.M. (1997) New estimates of global and regional coral reef areas. Coral Reefs 16: 225-230

Taylor, J.C., Eggleston, D.B., and Rand, P.S. (2006) Nassau grouper (Epinephelus striatus) spawning aggregations: hydroacoustic surveys and geostatistical analysis. NMFS Professional Paper: 18-25 
Tyler, E.H.M., Speight, M.R., Henderson, P., and Manica, A. (2009) Evidence for a depth refuge effect in artisanal coral reef fisheries. Biological Conservation 142: 652-667

Tzanatos, E., Somarakis, S., Tserpes, G., and Koutsikopoulos, C. (2008) Catch length analysis, relation to minimum landing sizes and management implications from a Mediterranean small-scale fishery (Patraikos Gulf, Greece). Fisheries Research 93: 125134

Walther, G.R., Post, E., Convey, P., Menzel, A., Parmesan, C., BeeBee, T.J.C., Fromentin, J.M., Hoegh-Guldberg, O., and Bairlein, F. (2007) Ecological responses to recent climate change. Nature 416: 390-395

Watson, R.A., Carlos, G.M., and Samoilys, M.A. (1995) Bias introduced by the nonrandom movement of fish in visual transect surveys. Ecological Modelling 77: 205-214

Wilson, S.K., Fisher, R., Pratchett, M.S., Graham, A.J, Dulvy, N.K., Turner, R.A., Cakacaka, A., and Polunin, N.V.C. (2010) Habitat degradation and fishing effects on the size structure of coral reef fish communities. Ecological Applications 20: 442-451

Yule, D.L., Evrard, L.M., Cachera, S., Colon, M., and Guillard, J. (2013) Comparing two fish sampling standards over time: largely congruent results but with caveats. Freshwater Biology 58 (10) 2074-2088. 


\section{Selected Figures}

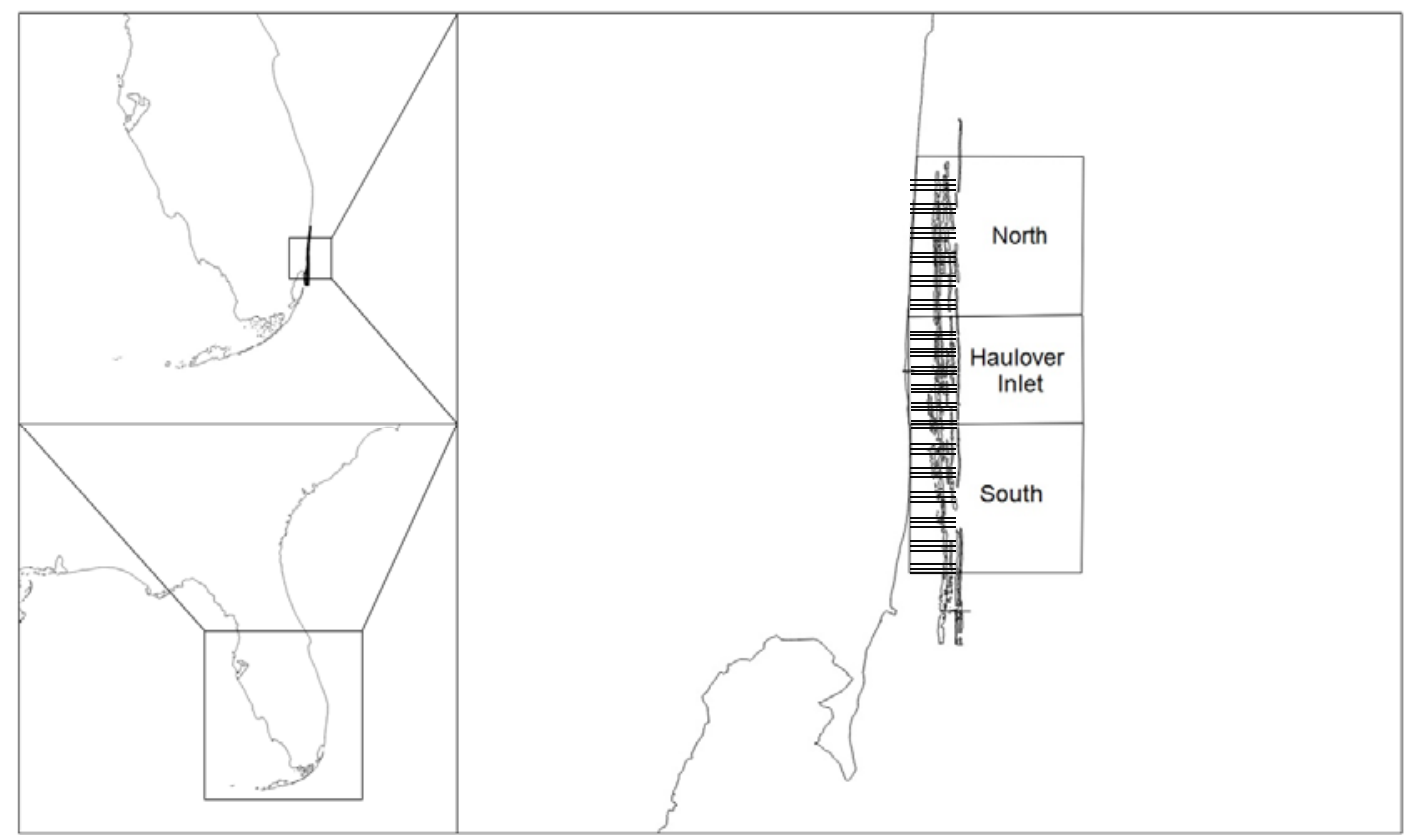

Figure 1. Range of survey strata in southeastern Florida. Individual strata contained 18 transects, 6 of which were randomly chosen on a given survey day. Benthic reef maps courtesy of SEFCRI (2011). 


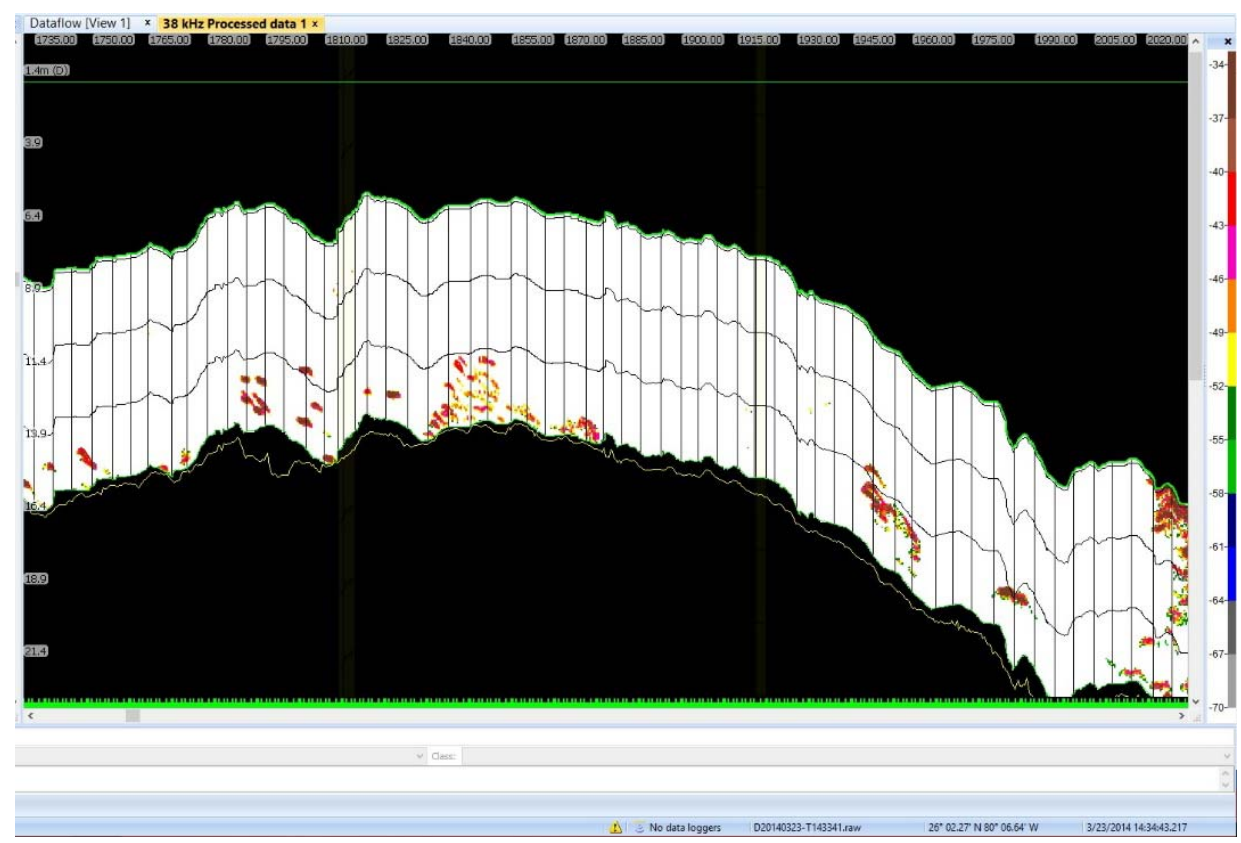

Figure 2. Representative $38 \mathrm{kHz}$ echogram of acoustic analysis showing many single targets across the third reef tract crest. 


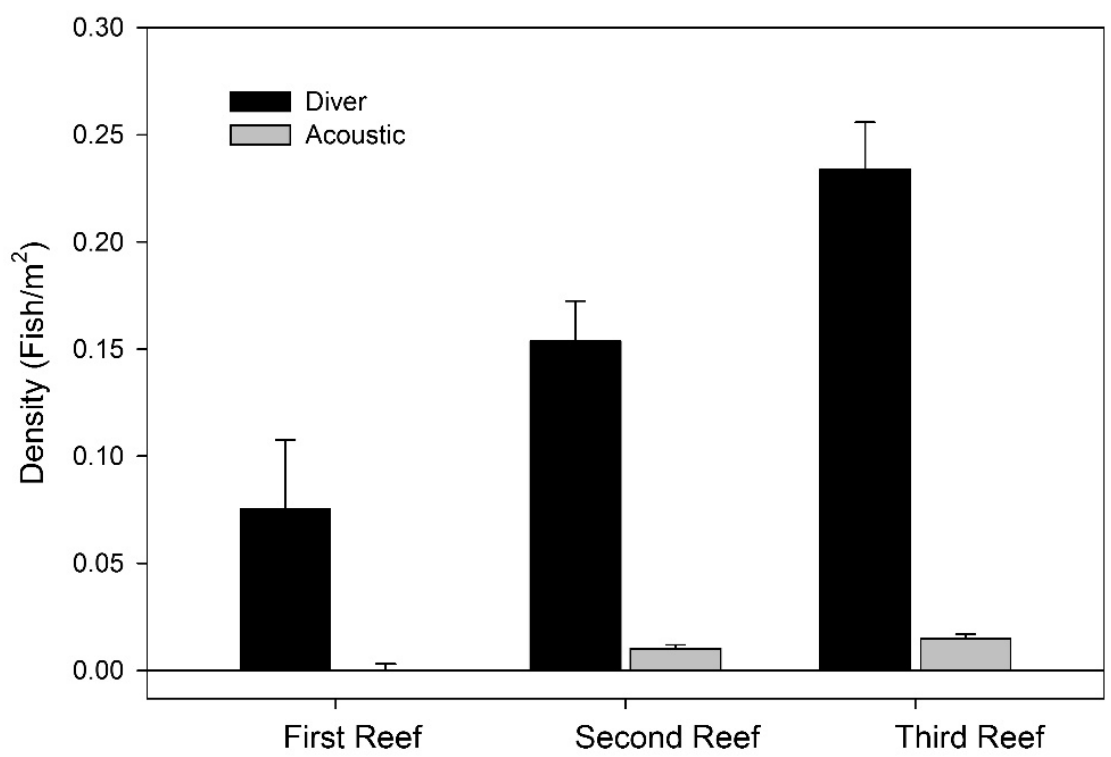

Figure 3. Fish density derived from both diver and acoustic surveys across all reef tracts. 


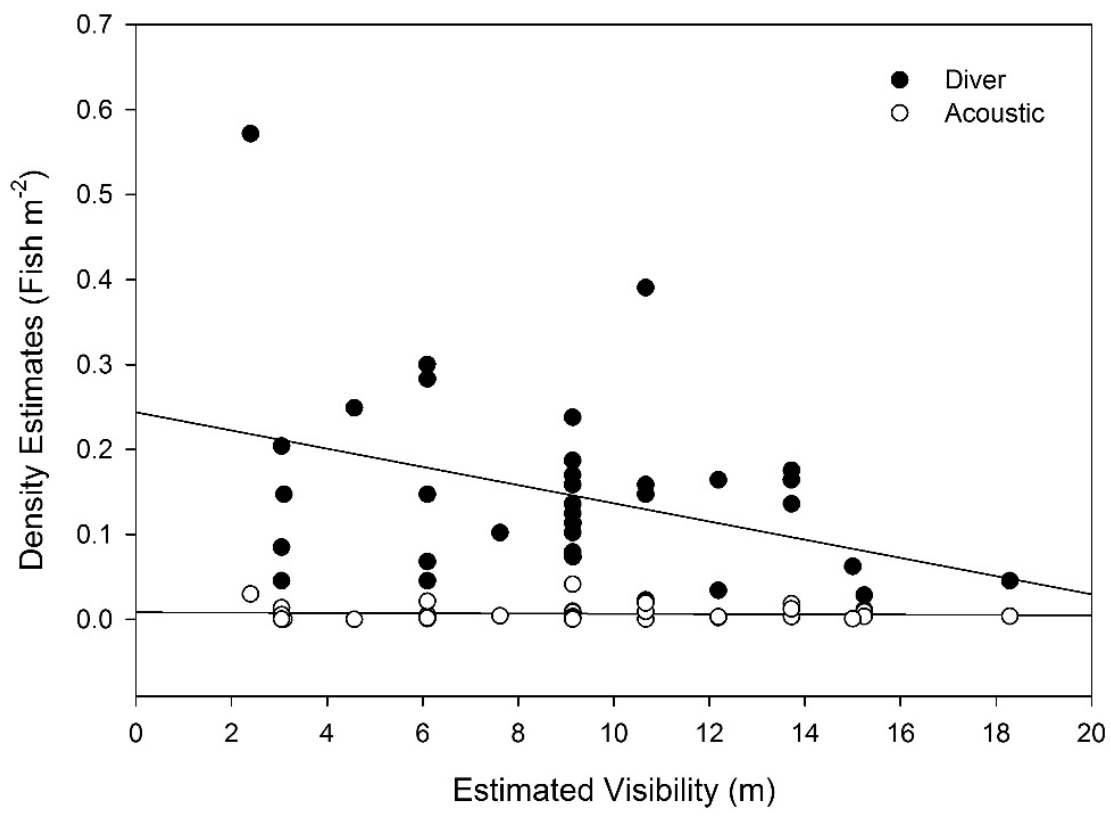

Figure 4. Linear regression of fish density estimates described by acoustic and diver surveys. 


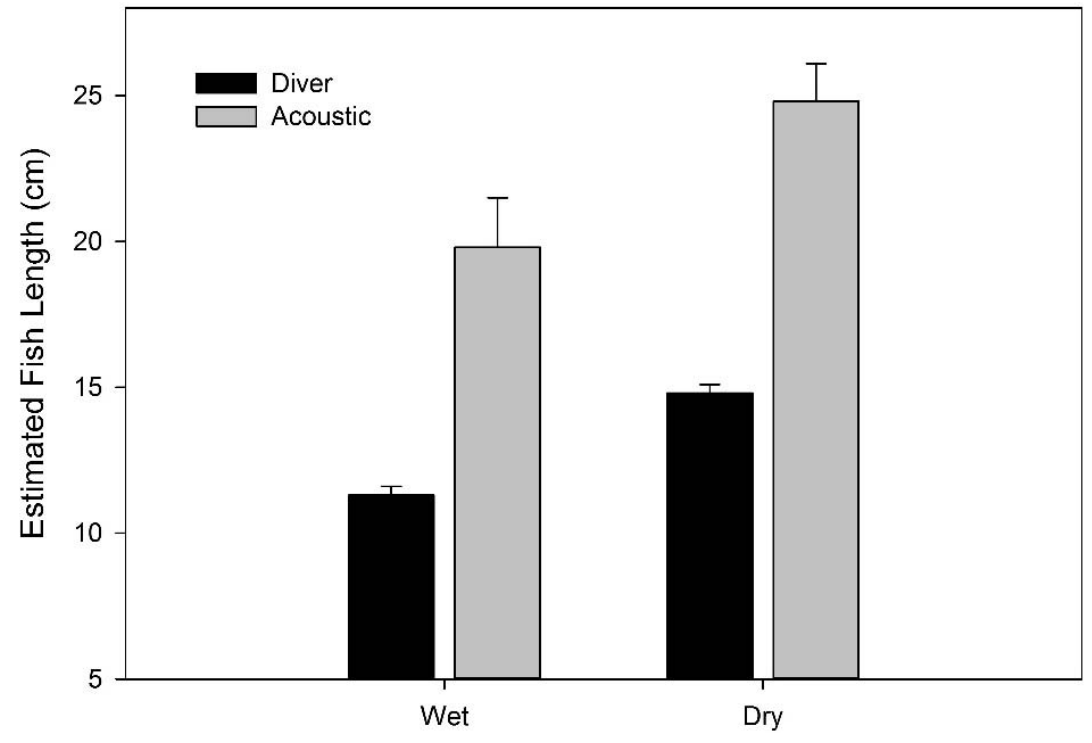

Figure 5. Comparison of fish length estimations between diver and acoustic surveys. Lengths between survey methods are different, however each shows an increase in average fish size between seasons. 


\begin{tabular}{lccccc}
\hline & \multicolumn{2}{c}{ Diver Density Estimates } & & \multicolumn{2}{c}{ Acoustic Density Estimates } \\
\cline { 2 - 3 } \cline { 5 - 6 } Source & $\mathrm{t}$ & $\mathrm{P}$ & & $\mathrm{t}$ & $\mathrm{P}$ \\
\hline Reef tract & 2.228 & 0.0338 & & 2.478 & 0.0193 \\
Strata & 1.471 & 0.1521 & & 1.399 & 0.1724 \\
Live Coral (\%) & 0.760 & 0.4535 & & -0.450 & 0.6561 \\
Depth (m) & -1.824 & 0.0785 & & -1.656 & 0.1084 \\
Visibility (m) & -2.455 & 0.023 & & -0.651 & 0.5200 \\
Reef tract* & -1.281 & 0.2104 & & -1.435 & 0.1620 \\
Strata & & & & & \\
\hline
\end{tabular}

Table 1. Results of generalized linear models using reef characteristics to predict estimates of density by both acoustic and diver methodologies. Significance was set at $\alpha$ $=0.05$ for all tests. 


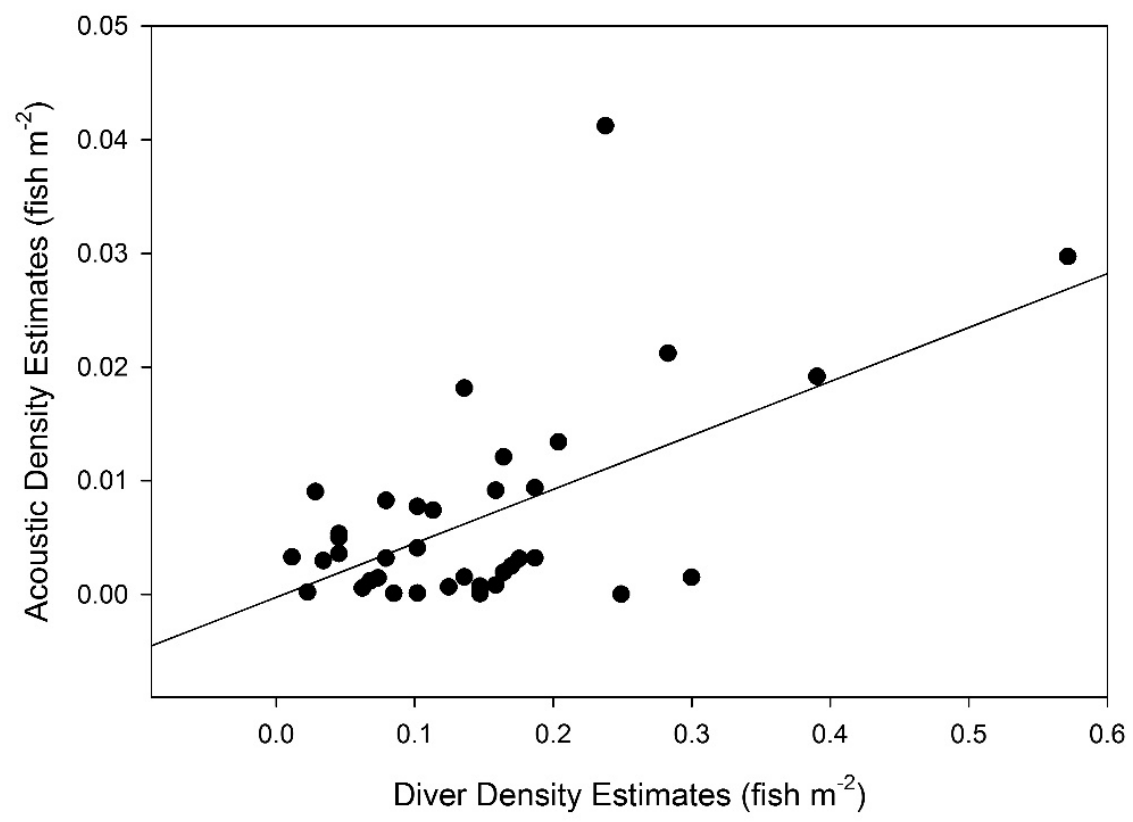

Figure 6.) Linear regression of diver density estimates and acoustic density estimates show a significant positive correlation. 
CHAPTER 3 - COMPOSITION, ABUNDANCE, AND DISTRIBUTIONS OF FISH COMMUNITIES ASSOCIATED WITH A HIGH LATITUDE CORAL REEF, FLORIDA, USA

\begin{abstract}
Hosting fish communities typically associated with a Caribbean coral reef, a series of Holocene relict ridge reefs in northern Miami-Dade County, Florida, USA, lie proximal to one of the most highly urbanized coastlines in the world. Despite both economic and ecological importance of these fish communities, scientific investigations to describe these fish assemblages are lacking. This is of particular importance given the increasing anthropogenic pressures being imposed on the coastal landscape and nearby reef ecosystem. To address this paucity of information, a combination of hydroacoustic and diver-based census methods were used to elucidate temporal and spatial patterns in fish composition, abundance, and distributions. Acoustic surveys found seasonal differences in estimates of nektonic biomass, with an increase associated with the local dry season. Examining patterns from diver-based surveys offer potential explanation for distributional differences found across reef sites, suggesting shallower reefs may function as a nursery for species that display an ontogenetic shift. Abundance data indicate a conspicuous depletion of apex predators in the region in comparison to more pristine reefs worldwide, further evidence of the high levels of local fisheries exploitation. Fish densities across the study area were generally low and displayed local variation, however in comparison to densities measured in other tropical reef ecosystems, South Florida reefs were the lowest. We consider potential management implications for the region, and
\end{abstract}


provide baseline data for future comparisons to the communities under increasing anthropogenic pressures.

\subsection{Introduction}

South Florida, USA, is home to the third largest barrier reef in the world, consisting in the north of a series of Holocene relict ridge reefs with distinct habitat-type characteristics along a gradient of increasing distance to shore (Figure 7). With increasing distance these reefs are classified as ridge complex, inner, middle, and outer linear reef (Banks et al., 2008). A substantial portion of these reefs run parallel to the coastline of Miami-Dade County, whose population of 2.6 million people participated in over 18 million recreational fishing trips in 2013 (FWC, 2013; US Census Bureau, 2013). This urbanization has led to the degradation of local reef tracts through a combination of anthropogenic pressures including increased nutrient loading, sedimentation, and fishing pressures that have contributed towards the depletion of important commercial fish species below sustainable levels (Lapointe et al., 2004; Ault et al., 2005, Paul et al., 2005; FL DEP, 2012;).

As anthropogenic influences on reef tracts increase, studies in the region have investigated pressures responsible for the decline of coral health, abundance, and species distributions (Moyer et al., 2003; Paul et al., 2005; Lirmen et al., 2011). Notable contributors to compromised reef health are anthropogenically sourced nutrients that lead to algal blooms in the region (Barile, 2004; Lapointe et al., 2005). These algal blooms peak in the summer months, or wet season, due to a combination of upwelling events, increased temperatures, and considerably higher rainfall contributing to regional and concentrated runoff (Jaap and Adams, 1984; Lirmen and Biber, 2005). Typically reef 
herbivores are able to compensate for algal growth, however, either through pre-existing community composition or removal by fisheries activity, localized grazer abundance is not adequate to prevent the smothering of corals by algal blooms (Carpenter and Edmunds, 2006). A Caribbean-wide die-off and the subsequent lack of recovery of a primary reef herbivore, the urchin Diadema antillarum, has further exacerbated increasing benthic algal coverage in the region (Lessios, 1988; Levitan, 1988; Chiappone et al., 2002).

Despite the knowledge that decreased coral coverage results in a concomitant decrease in fish community health, few peer-reviewed studies concern the fish assemblages utilizing these reefs as habitat (Jones et al., 2004; Cheal et al., 2008). Primarily ignored in the literature, descriptions of northern Miami-Dade County fish communities by fisheries independent studies are limited to assessments of artificial reef health (Jordan, 2005; Walker et al., 2009; Ault and Franklin, 2011; Gregg, 2013). Given the economic and ecological significance of the reef tracts in northern Miami-Dade County, it is critical to describe local reef communities both spatially and temporally to assess the health of important fish assemblages.

In this paper we present the results of one of the first fisheries-independent surveys of northern Miami-Dade County primarily interested in describing reef fish communities. We examine biomass distributions across the county with hydroacoustic surveys, and then provide community level context through concurrent diver surveys to consider explanations for shifts in biomass. Our surveys provide data from which we may examine future effects of increasing urbanization on reef fish communities. Further, our 
results will serve as a first step in filling the apparent dearth of fish assemblage information in the region.

\subsection{Methods and Materials}

Study Site

Our study area ranges from approximately $6 \mathrm{~km}$ south of Pt. Everglades in Ft. Lauderdale $\left(26.03312^{\circ},-80.072672^{\circ}\right)$ at the very southern portion of Broward county, to $3 \mathrm{~km}$ north of Government Cut, near South Miami Beach $\left(25.779022^{\circ},-80.062706^{\circ}\right)$. For the purposes of this study only the three reef tracts classified as "linear" (Figure 7) were surveyed, as structural similarities allowed for the most direct observations of community changes.

A random stratified sampling design was applied with each of three strata (North, Haulover Inlet, and South) being divided into 6 substrata. In each substrata, three evenly spaced transect lines running perpendicular to linear reef tracts were created (Figure 7). During each sampling event, a single transect line was randomly selected within each sub-strata, yielding six total transects surveyed per strata, per survey day. Survey days were selected based on wave heights below $1 \mathrm{~m}$ to ensure data were of high quality. To complement hydroacoustic surveys, two of the six acoustic transects were randomly selected and complemented with diver-based surveys. To control for temporal variation, all diver-based surveys and acoustic transects were conducted on the same day, with at least 30 minutes between each method to normalize fish behavior. Surveys ran from August of 2013 through March, 2014 with each strata surveyed twice per month, for a total of 174 acoustic transects with 42 complemented by divers.

Acoustic Surveys 
Acoustic data were collected using a calibrated Simrad EK60 multi-frequency echosounder system operating 38 and $120 \mathrm{kHz}$ split-beam transducers interfaced to a laptop computer running ER60 software (SIMRAD, v2.0). The survey vessel was driven along each transect at an average speed of $2 \mathrm{~m} \mathrm{~s}^{-1}$, with position recorded by a WASSenabled USB Garmin GPS corrected for positional offsets from the face of the transducer. Transducers were mounted to the survey vessel by an articulated mounting pole allowing for easy deployment into a downward facing position and were calibrated by the standard sphere method prior to surveys (Foote et al., 1987). Echoview 6.1 (Sonar Data Pty., Ltd.) was the primary program used in the post-processing of acoustic data. An analysis threshold was applied to the volume backscattering strength $\left(\mathrm{S}_{V}\right.$, in $\left.\mathrm{dB}\right)$ echogram in conjunction with a bottom detection algorithm to remove extraneous backscatter (ie. benthic habitat, air bubbles, and dissolved organic matter). Echograms were then manually examined for remaining undesired data and binned into a $2.5 \mathrm{~m}$ horizontal by $2.5 \mathrm{~m}$ depth grid, and volume backscatter was derived for each $2.5 \mathrm{~m} \times 2.5 \mathrm{~m}$ cell following standard echo integration techniques (Simmonds and MacLennan, 2005. Estimates of the volume backscattering coefficient $\left(\mathrm{s}_{\mathrm{v}}\right)$, which is proportional to fish biomass, were converted from the decibel domain to arithmetic form $\left[\mathrm{S}_{V}=10 * \log _{10}\left(\mathrm{~S}_{\mathrm{V}}\right)\right]$ and used for all statistical analyses. Target strength, a measure of fish size, was converted to length (L; cm) following the general model proposed by Love (1977), where A and B are the slope and intercept of a length and target strength regression:

$$
\mathrm{TS}=\mathrm{A} * \log 10(\mathrm{~L})+\mathrm{B}
$$

As residuals of the $\mathrm{s}_{\mathrm{v}}$ estimates did not approximate a normal distribution with standard parametric analysis under any transformation, non-parametric methods of 
analysis were adopted and applied in SigmaPlot (Version 12.5, Systat Software, Inc). A Kruskal-Wallis one-way ANOVA on ranks was used to test for differences in $\mathrm{s}_{\mathrm{v}}$ and fish length among strata, reef tract, and season. Post-hoc analysis used Dunn's Method of multiple pairwise comparisons at an alpha level of 0.05 . A Mann-Whitney rank sum test was then used to examine differences in $\mathrm{s}_{\mathrm{v}}$ between both the wet and dry season.

\section{Diver Surveys and Community Distributions}

Divers were deployed in teams of two at sites located in the center of each linear reef tract with a GPS laden dive flag to verify survey location. A modified reef visual census was applied to record fish species, estimated length, abundance, and reef characteristics of interest (Smith et al., 2011). To minimize diver collection bias, all divers were subject to quizzes on reef fish identification and length estimation prior to any survey action following SEFCRI (2012). Estimates of total fish length $(\mathrm{cm})$ recorded by divers were used to derive biomass according to species-specific length-weight coefficients (Eq. 1) (Gandara et al., 2003; Gonzalez-Mendes et al., 2004; BouchonNavaro et al., 2006; Ladd, 2011). As in similar studies, species lacking specific lengthweight coefficients were estimated with the most closely related and sized fish following the standard allometric relationships (Ackerman and Bellwood, 2000).

$$
\text { Weight }(\mathrm{g})=\log (\mathrm{a})+\mathrm{b} * \log (\mathrm{L})
$$

To examine community characteristics and species distributions across the county, fish abundance data recorded by divers were square root transformed and examined through a Bray-Curtis dissimilarity matrix. A Bray-Curtis dissimilarity value is bound between 0 and 1 , with higher values indicating increasingly disparate species compositions between given sites (Bray and Curtis, 1957). Using this matrix, a principle- 
components ordination (PCO) (Primer 6 and Permanova + V. 1.0.2) was created. Unlike another common method for elucidating community patterns, e.g., multidimensional scaling, a PCO graph clusters data points based upon quantitative dissimilarity values rather than ranks of dissimilarity. This preserves covariance among factors and is a good alternative to data that may not conform well to multidimensional scaling techniques (Anderson and Willis, 2003). Factors important in explaining these trends were analyzed for significance using a permutational MANOVA (PERMANOVA) with type 3 partial sums of squares. A PERMANOVA uses permutation methods to test the simultaneous response of several variables to multiple factors within an ANOVA design on the basis of a distance measure (Anderson, 2005). A two way crossed Bray-Curtis similarity percentage routine (SIMPER) was then used to determine unique species important in explaining variance between reef communities in season and strata. Using the biomass calculated by length-weight coefficients, community composition expressed as percent biomass was analyzed by family and species among strata, season, and reef tract. Finally, a meta-analysis of literature reporting areal density on coral reefs was conducted to compare densities of reef fishes in northern Miami-Dade County with reefs in other locations spanning a spectrum of anthropogenic pressures.

\subsection{Results}

Acoustic Surveys

We found a significant increase in acoustic estimates of biomass $\left(\mathrm{s}_{\mathrm{v}}\right)$ in the dry season as compared to the wet (Figure $8, \mathrm{P}=0.001, \mathrm{~N}=500, \mathrm{DF}=1$ ). Across both seasons strata did not have significantly varying estimates of $s_{v}(P>0.05)$. Significant differences in $\mathrm{s}_{\mathrm{v}}$ were also found between linear reef tracts, which show similar values 
between the second and third reef tract and an increase in biomass on the first reef tract

(Figure 9, $\mathrm{P}<0.001, \mathrm{~N}=501$ ). Post-hoc analyses show the first reef tract has

significantly higher estimates of $\mathrm{S}_{\mathrm{v}}$ than the second and third reef tract (Dunns: $\mathrm{P}<0.05$ ).

Reef tract biomass estimates were then tested across season, revealing a significant difference between each reef tract $\mathrm{s}_{\mathrm{v}}$ estimates in both the wet and dry season (Wet $\mathrm{P}<$ $0.001, \mathrm{~N}=279, \mathrm{DF}=2 ;$ Dry $\mathrm{P}<0.001, \mathrm{~N}=224, \mathrm{DF}=2$ ). Notably, the first reef tract had a higher $\mathrm{s}_{\mathrm{v}}$ in the dry season than the same reef tract in the wet season (Figure 10, MannWhitney Rank Sum $\mathrm{P}<0.001, \mathrm{n}=168)$.

Fish length estimated from target strength (TS) varied significantly between the wet and dry season with an average length of $19.775( \pm 1.689)$, and $24.804( \pm 1.282) \mathrm{cm}$ respectively, but was not found to be variable across reef tracts (Figure $8, \mathrm{P}<0.001, \mathrm{n}=$ 242).

\section{Diver Surveys and Community Distributions}

A total of 42 linear reef sites were surveyed concurrently with acoustic survey methods (see Chapter 2). During these surveys, 2837 individuals from 78 species across 23 families were identified. The top three dominant reef families were primarily herbivorous, with the family Pomacanthidae (Angelfishes) contributing $25.5 \%$ to overall reef biomass (Table 2). Across season, family contributions changed little, with the Labrid fishes resulting in the only notable change in family composition (Table 3.). Biomass contributions across strata show a continued dominance by Pomacanthidae in the North and South, though interestingly absent in the Haulover Inlet strata. The Haulover Inlet strata was dominated by the predatory bar jack, Caranx ruber, and was 
accompanied by the highest abundance of predatory fish in the top 10 biomass contributors among strata (Table 4).

Results of the PCO on species abundance indicate a clear and significant grouping of sites found between strata and a weaker but significant correlation between sites found in different seasons $(\mathrm{P}=0.032, \mathrm{P}=0.014$, PERMANOVA) (Figure 12). SIMPER analysis indicated an average dissimilarity of 81.55 between seasons, and 77.50 between all strata. Over half of the dissimilarity between seasons can be accounted for by abundance changes in only 8 species (Table 5). The top three contributors to these differences show variability in seasonal detections across linear reef tracts. Notably, Haemulon flavolineatum show a major increase in abundance on the third reef between wet and dry season (Wet Season: 7.7\%, Dry Season: 94.4\%) while Acanthurus bahianus shows an opposite trend in abundance (Wet Season: 68.9\%, Dry Season: 33.3\%) (Figure 12). A significant linear relationship was found between latitude and species richness, indicating that species richness increases with decreasing latitude (Figure 13) $\left(\mathrm{R}^{2}=\right.$ $0.1907, \mathrm{P}<0.05)$.

\subsection{Discussion}

The acoustic surveys in this study provide what we believe is a synoptic regionwide, fisheries-independent survey of reef fish biomass in northern Miami-Dade County. As in other reef systems, we observed a significant increase in biomass between the dry and wet seasons across all reef types and strata, particularly in the first reef tract (Mellin et al., 2007). Based on the community analyses, the primary drivers in this difference are attributable to Haemulon flavolineatum, Acanthurus bahianus, and Balistes capriscus.

Although these species are not the biggest contributors to overall biomass, examination 
of species abundance across reef tracts between seasons show considerable differences between reef tract utilization, primarily showing a shift between the first and third reef tracts.

The possibility exists that this change across reef tracts is the result of an ontogenetic shift by structuring species. Supporting this supposition are the acoustic length estimates of single fish targets that show an increase in average fish size between seasons. Further, primary drivers in community differences, principally by $H$. flavolineatum and A. bahianus, along with several species of local commercial importance, are among species that have been documented to utilize disparate reef habitats in specific life stages (Nalgerken and van der Velde, 2004; Appeldoorn et al., 2009). Though preferentially using mangrove and seagrass habitat as a nursery, $H$. flavolineatum have been known to inhabit shallow reefs in the absence of suitable mangrove or seagrass habitat (Nalgerken et al., 2000; Adams and Ebersole, 2002). Here, as elsewhere, we will use abundance patterns of $H$. flavolineatum as a representative of fishes known to undergo ontogenetic shifts (Huijbers et al., 2008; Nalgerken et al., 2008). Indeed, surveys in nearby Broward County have shown that juvenile grunts comprise the majority of biomass on the inner reef tracts, with over $85 \%$ of fish detections on those reefs being a juvenile stage (Baron et al., 2004). Our data corroborate this, as $H$. flavolineatum comprises the second highest contributor of biomass in the North strata, on reefs closer to Broward County. These contributions to biomass by the Haemulids decline toward the south, potentially as a result of increased species richness. Proximity of both the Haulover Inlet and South strata to seagrass beds in Biscayne Bay may also result in the preferential settlement of juveniles off shallow-reef habitat. 
Given widespread coastal urbanization, historic removal of mangrove habitat on the shoreline in northern Miami-Dade, anticipated sea level rise, and absence of ecologically significant seagrass beds north of Biscayne National Park, the first reef tract may be an increasingly important habitat for fish communities in the region (Doyle et al., 2003; SEFCRI, 2011). As stated by Adams et al., 2006, "knowledge of habitat specific nursery function would... allow managers to better predict multi-species population trends and implement adaptive management practices for species or groups of... management interest". Data presented here suggest that plans seeking to manage reefs in northern Miami-Dade County should not neglect the importance of the first reef tract as a potential nursery habitat.

Separate analysis of commercial and recreational catches in Miami-Dade County show many predatory fish of commercial importance have been removed well below sustainable levels (Ault and Franklin, 2011). In stark contrast to biomass contributions on a comparatively healthy reef in the Gulf of Mexico (Flower Gardens), abundance data show communities in northern Miami-Dade County are dominated primarily by nonpredatory fishes, which comprise $61.52 \%$ of community biomass by family. Further, 7 of the top 10 contributors to biomass in the Flower Gardens are considered apex predators, compared to only 3 of the top 10 in northern Miami-Dade County. It appears that predator declines may be directly associated with increased anthropogenic pressure in Miami-Dade County, as is the case elsewhere in the Caribbean (Stallings, 2009).

Though not typically a primary driver to regime shifts, the removal of predators from a coral reef in conjunction with other pressures can elicit a shift from a coral dominated benthos to a macroalgal one (McClanahan, 1995; Dahlgren and Eggleston, 
2000; McClanahan et al., 2002; Dulvy et al., 2004; Eriksson et al., 2009). A decrease in predators would typically result in an ecological release of prey species such as herbivorous fishes or echinoderms, however this effect is likely to be minimal on reefs in northern Miami-Dade County with comparatively low fish densities (McClanahan and Muthiga, 1988). Further, the primary herbivorous echinoderm, Diadema antillarum, has never recovered from a Caribbean-wide die-off. Those few individuals that remain have little structuring effect on algal growth and are unlikely to ameliorate algal blooms (Hughes, 1994). Despite a high percentage of biomass comprised of reef herbivores, it appears that overfishing and previously documented nutrient increases may leave reef systems in northern Miami-Dade County vulnerable to a regime shift resulting in severe declines of reef habitat function (Barile, 2004; Lapointe et al., 2004; Lapointe et al., 2005; Pandolfi et al., 2005).

Fish communities in northern Miami-Dade County display declined reef health in comparison to geographically similar reefs, and are significantly variable across both temporal and spatial scales. We believe the first reef tract may potentially serve as a critical nursery habitat to those species whose life histories contain an ontogenetic shift, particularly those of commercial interest such as $\mathrm{H}$. flavolineatum. Community analyses indicate that fish assemblages in the North strata are structured similarly to reefs surveyed in Broward County, whereas South strata communities may be distinctly different from the other studied strata. The surveys described here detected potentially the lowest average densities (fish $\mathrm{m}^{-2}$ ) of reef fish on a global scale from available literature (Figure 14). While alarming, this cannot be explained merely by the high latitude of these habitats, as reefs geographically proximal to Miami-Dade County (Broward County and 
the Florida Keys) exhibit far higher densities and richness of reef species. One potential explanation is the increased local anthropogenic pressures which may already have resulted in significant declines in overall reef community health.

Given that these communities are described only sparsely in the literature, this information can serve as a starting point for exploring future changes in fish community distributions. Further, our results appear to show promise in utilizing diver surveys to provide community level context of fish communities that can potentially be extrapolated to wide-scale results of acoustic surveys. Here, we were able to observe region-wide changes in fish densities as recorded by acoustic surveys that were potentially explained by shifting species compositions of reef communities as observed by divers. Further work is necessary to assess the validity of data collected by disparate survey methods, but conclusions drawn from complementary methods are encouraging. Finally, it is our hope that these data will prove useful to those seeking improved management policies that may begin to ameliorate pressures from the highly urbanized coastline of Miami-Dade County. 


\section{References}

Ackerman, J.L., and Bellwood, D.R. (2000) Reef fish assemblages: a re-evaluation using enclosed rotenone stations. Marine Ecology Progress Series 206: 227-237

Adams, A.J., and Ebersole, J.P. (2002) Use of back-reef and lagoon habitats by coral reef fishes. Marine Ecology Progress Series 228: 213-226

Adams, A.J., Dahlgren, C.P., Kellison, G.T., Kendall, M.S., Layman, C.A., Ley, J.A, Nagelkerken, I., and Serafy, J.E. (2006) Nursery function of tropical back-reef systems. Marine Ecology Progress Series 318: 287-301

Anderson, M.J. (2005) Permutational multivariate analysis of variance. Department of Statistics, University of Auckland, Auckland.

Appeldoorn, R.S., Aguilar-Perera, A., Bouwmeester, B.L.K., Dennis, G.D., Hill, R.L., Merten, W., Recksiek, C.W., and Williams, S.J. (2009) Movement of fishes (Grunts: Haemulidae) across the coral reef seascape: A review of scales, patterns and processes. Caribbean Journal of Science 45(2-3): 304-316

Ault, J.S., Smith, S.G., and Bohnsack, J.A. (2005) Evaluation of average length as an estimator of exploitation-n status for the Florida coral-reef fish community. ICES Journal of Marine Science 62: 417-423

Ault, J.S., and Franklin, E.C. (2011) Fisheries Resource Status and Management Alternatives for the Southeast Florida Region. Report to Florida DEP. Miami Beach, FL. Pp 105

Banks, K.W., Riegl, B.M., Richards, V.P., Walker, B.K., Helmle, K.P., Jordan, L.K.B., Phipps, J., Shivji, M.S., Spieler, R.E., and Dodge, R.E. (2008) The Reef Tract of Continental Southeast Florida (Miami-Dade, Broward and Palm Beach Counties, USA). Coral Reefs of the USA, Springer Science+Business Media: 175- 219

Barile, P.J. (2004) Evidence of Anthropogenic Nitrogen Enrichment of the Littoral Waters of East Central Florida. Journal of Coastal Research 20: 1237-1245

Baron, R.M., Jordan, L.K.B., and Spieler, R.E. (2004) Characterization of the marine fish assemblage associated with the nearshore hardbottom of Broward County, Florida, USA. Estuarine, Coastal, and Shelf Science 60: 431-443

Bouchon-Navaro, Y., Bouchon, C., Kopp, D., and Louis, M. (2006) Weight-length relationships for 50 fish species collected in seagrass beds of the Lesser Antilles. Journal of Applied Ichthyology 22: 322-324

Bray, J.R., and Curtis, J.T. (1957) An Ordination of the Upland Forest Communities of Southern Wisconsin. Ecological Monographs 27 (4): 325-349 
Carpenter, R.C., and Edmunds, P.J. (2006) Local and regional scale recovery of Diadema promotes recruitment of scleractinian corals. Ecology Letters 9: 271-280

Cheal, A.J., Wilson, S.K., Emslie, M.J., Dolman, A.M., and Sweatman, H. (2008) Responses of reef fish communities to coral declines on the Great Barrier Reef. Marine Ecology Progress Series 372: 211-223

Chiappone, M., Swanson, D.W., Miller, S.I., and Smith, S.G. (2002) Large-scale surveys on the Florida Reef Tract indicate poor recovery of the long-spined sea urchin Diadema antillarum. Coral Reefs 21: 155-159

Dahlgren, C.P., and Eggleston, D.B. (2000) Ecological processes underlying ontogenetic habitat shifts in a coral reef fish. Ecology 81(8): 2227-2240

Doyle, T.W., Girod, G.F., Books, M.A. (2003) Modeling mangrove forest migration along the southwest coast of Florida under climate change. Preparing for a changing climate: the potential consequence of climate variability and change: Gulf Coast region, 211-222

Dulvy, N.K., Freckleton, R.P., and Polunin, N.V.C. (2004) Coral reef cascades and the indirect effects of predator removal by exploitation. Ecology Letters 7: 410-416

Eriksson, B.K., Ljunggren, L., Sandstrom, A., Johansson, G., Mattila, J., Rubach, A., Raberg, S., and Snickars, M. (2009) Declines in predatory fish promote bloom-forming macroalgae. Ecological Applications 19(8): 1975-1988

Florida Fish and Wildlife Commission (2013). Annual fisheries data report, myfwc.com.

Foote, K.G. (1980) Effect of fish behaviour on echo energy: the need for measurements of orientation distributions. Journal du Conseil International pour l'Exploriation de la Mer 39. 193-201.

Gilliam, D.S., Brinkhuis, V., Ruzicka, R., and Walton, C.J. (2013) Southeast Florida Coral Reef Evaluation and Monitoring Project 2012 Year 10 Final Report. Florida DEP Report \#RM085. Miami Beach, FL. pp 53

Gonzalez-Gandara, C., Perez-Diaz, E., Santos-Rodriguez, L., and Arias-Gonzalez, J.E. (2003) Length-weight relationships of coral reef fishes from the Alacran Reef, Yucatan, Mexico. Naga 26(1): 14-16

Gregg, K. (2013) Management Considerations for the Southeast Florida Coral Reef Ecosystem. Report to the National Oceanic and Atmospheric Administration, Coral Reef Conservation Program and the National Marine Fisheries Service. West Palm Beach, FL. Pp 42 
Hughes, T.P. (1994) Catastrophes, Phase Shifts, and Large-Scale Degradation of a Caribbean Coral Reef. Science 265: 1547-1551

Huijbers, C.M., Mollee, E.M., and Nagelkerken, I. (2008) Post-larval French grunts (Haemulon flavolineatum) distinguish between seagrass, mangrove and coral reef water: Implications for recognition of potential nursery habitats. Journal of Experimental Marine Biology 357: 134-139.

Jaap, W.C., and Adams, J.K. (1984) THE ECOLOGY OF THE SOUTH FLORIDA CORAL REEFS: A COMMUNITY PROFILE. Fish and Wildlife Service report MMS 84-0038. St. Petersburg, FL. pp 10

Jones, G.P., McCormick, M.I., Srinivasan, M., and Eagle, J.V. (2004) Coral decline threatens fish biodiversity in marine reserves. PNAS 101: 8251-8253

Jordan, L.K.B., Gilliam, D.S., and Spieler, R.E. (2005) Reef fish assemblage structure affected by small-scale spacing and size variations of artificial patch reefs Journal of Experimental Marine Biology and Ecology 326: 170-186

Ladd, M. (2011) Managing for Resilience: Practical Applications of Marine Science to Improve Natural Resource Management: A Case Study in the Puerto Morelos Marine Protected Area. FIU Electronic Theses and Dissertations. pp 177

Lapointe, B.E., Barile, P.J., and Matzie, W.R. (2004) Anthropogenic nutrient enrichment of seagrass and coral reef communities in the Lower Florida Keys: discrimination of local versus regional nitrogen sources. Journal of Experimental Marine Biology and Ecology 308: $23-58$

Lapointe, B.E., Barile, P.J., Littler, M.M., Littler, D.S., Bedford, B.J., and Gasque, C. (2005) Macroalgal blooms on southeast Florida coral reefs I. Nutrient stoichiometry of the invasive green alga Codium isthmocladum in the wider Caribbean indicates nutrient enrichment. Harmful Algae 4: 1092-1105

Lessios, H.A. (1988) Mass Mortality of Diadema Antillarum in the Caribbean: What Have We Learned? Annual Review of Ecology and Systematics 19: 371-393

Lirman, D., and Biber, P. (2000) Seasonal Dynamics of Macroalgal Communities of the Northern Florida Reef Tract. Botanica Marina 43: 305-314

Lirman, D., Schopmeyer, S., Manzello, D., Gramer, L.J., Precht, W.F., Muller-Karger, F., Banks, K., Barnes, B., Bartels, E., Bourque, A., Byrne, J., Donahue, S., Duquesnel, J., Fisher, L., Gilliam, D., Hendee, J., Johnson, M., Maxwell, K., McDevitt, E., Monty, J., Rueda, D., Ruzicka, R., Thanner, S. (2011) Severe 2010 Cold-Water Event Caused 
Unprecedented Mortality to Corals of the Florida Reef Tract and Reversed Previous Survivorship Patters. PLOS One 6: 1-10

McClanahan, T.R., and Muthiga, N.A. (1988) Changes in Kenyan coral reef community structure and function due to exploitation. Hydrobiologia, 166(3): 269-276

Barile, P.J. (2004) Evidence of Anthropogenic Nitrogen Enrichment of the Littoral Waters of East Central Florida. Journal of Coastal Research 20: 1237-1245

McClanahan, T.R. (1995) A coral reef ecosystem-fisheries model: impacts of fishing intensity and catch selection on reef structure and processes. Ecological Modelling 80: 119

McClanahan, T., Polunin, N.C., Done, T. (2002) Ecological states and the resilience of coral reefs. Conservation Ecology 6: 18

Mellin, C., Kulbicki, M., and Ponton, D. (2007) Seasonal and ontogenetic patterns of habitat use in coral reef fish juveniles. Estuarine, Coastal, and Shelf Science 75: 481-491

Mendes, B., Fonseca, P., and Campos, A. (2004) Weight-length relationships for 46 species of the Portuguese west coast. Journal of Applied Ichthyology 20: 355-361

Moyer, R.P., Riegl, B., Banks, K., and Dodge, R.E. (2003) Spatial patterns and ecology of benthic communities on a high-latitude South Florida (Broward County, USA) reef system. Coral Reefs 22: 447-464

Nagelkerken, I., van der Velde, G., Gorissen, M.W., Meijer, G.J., van't Hof, T., and den Hartog, C. (2000) Importance of Mangroves, Seagrass Beds and the Shallow Coral Reef as a Nursery for Important Coral Reef Fishes, Using a Visual Census Technique.

Estuarine, Coastal and Shelf Science 51: 31-44

Nagelkerken, I., and van der Velde, G. (2004) Relative importance of interlinked mangroves and seagrass beds as feeding habitats for juvenile reef fish on a Caribbean island. Marine Ecology Progress Series 274: 153-159

Nagelkerken, I., Blaber, S.J.M., Bouillon, S., Green, P., Haywood, M., Kirton, L.G., Meynecke, J.O., Pawlik, J., Penrose, H.M., Sasekumar, A., and Somerfield P.J. (2008) The habitat function of mangroves for terrestrial and marine fauna: A review

Pandolfi, J.M., Jackson, J.B.C., Baron, N., Bradbury, R.H., Guzman, H.M., Hughes, T.P., Kappel, C.V., Micheli, F., Ogden, J.C., Possingham, H.P., and Sala, E. (2005) Are U.S. Coral Reefs on the Slippery Slope to Slime? Science 307: 1725-1726

Results of the 2010 national census (2013) United States Census Bureau. 
Simmonds, E.J., and MacLennan, D.N. (2005) Fisheries Acoustics: Theory and Practice, $2^{\text {nd }}$ edn. Blackwell Science, Oxford

Southeast Florida Coral Reef Initiative (2011)www.dep.state.fl.us/coastal/programs/coral/reports

Stallings, C.D. (2009) Fishery-Independent Data Reveal Negative Effect of Human Population Density on Caribbean Predatory Fish Communities. PLOS One 4: e5333

Walker, B.K., Jordan, L.K.B., and Spieler, R.E. (2009) Relationship of Reef Fish Assemblages and Topographic Complexity on Southeastern Florida Coral Reef Habitats. Journal of Coastal Research 53: 39-48 


\section{Selected Figures}

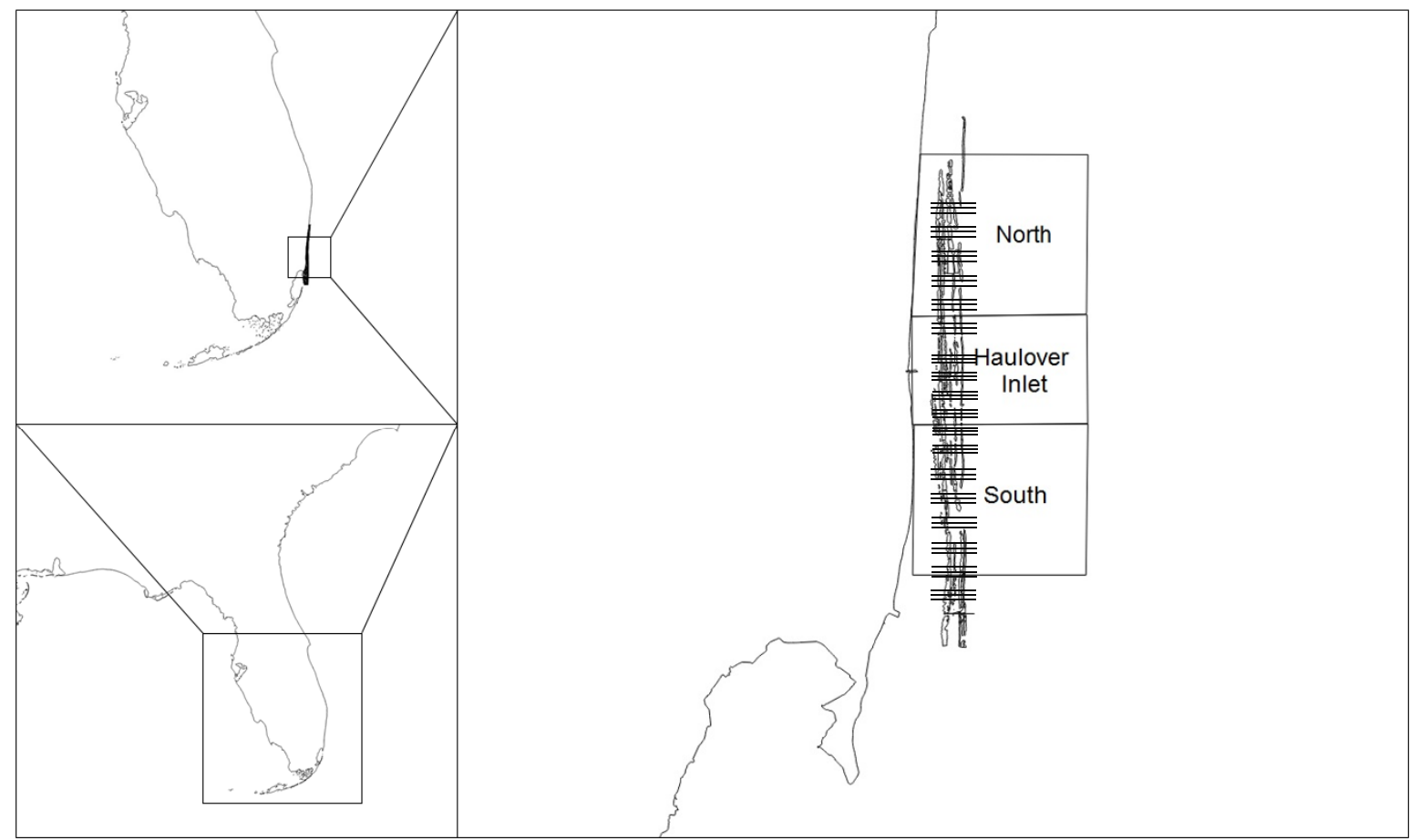

Figure 7.) Region of Northern Miami-Dade County surveyed during the study. In the right hand panel, the three contiguous reef tracts run parallel to shore, north to south. 


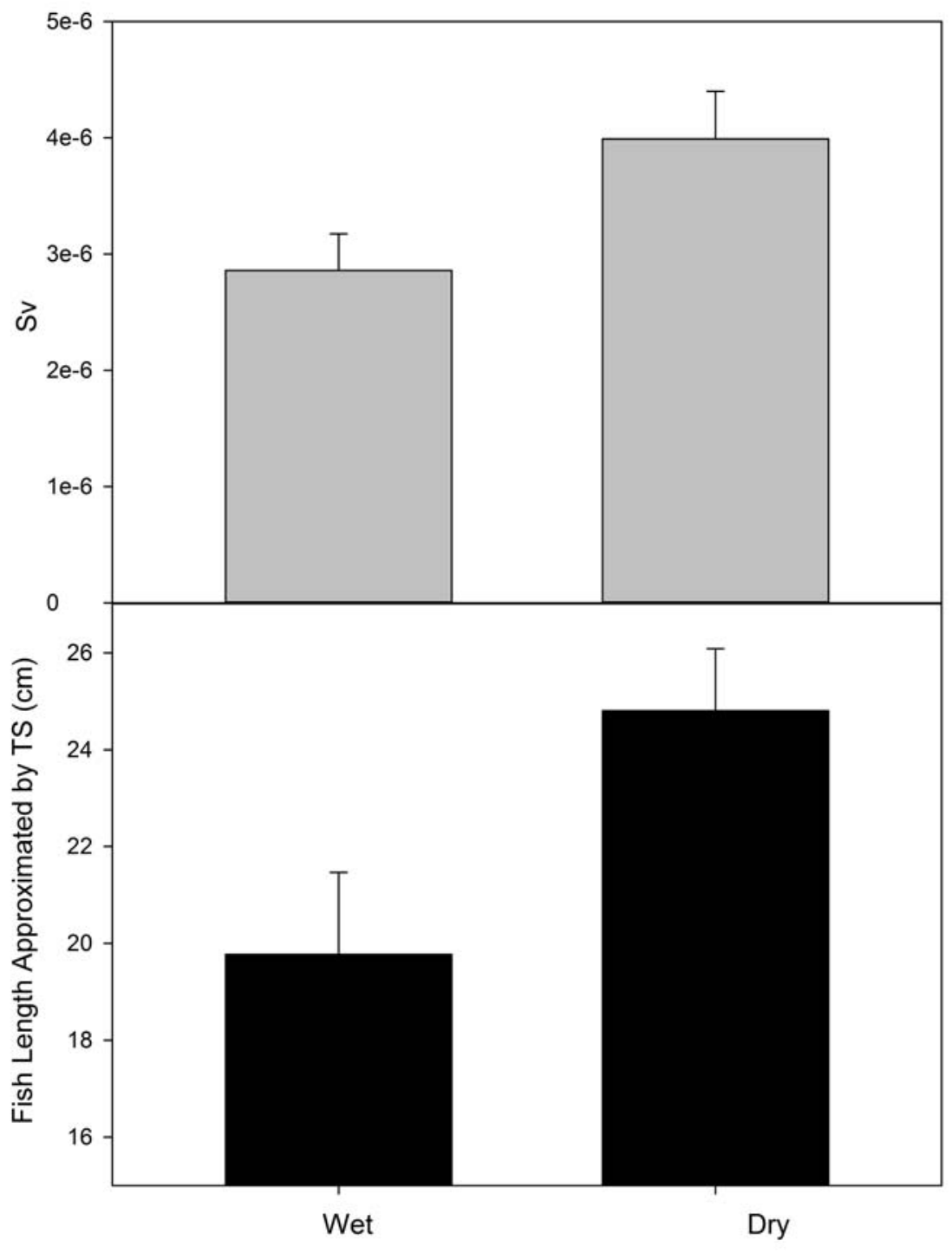

Figure 8.) Differences between the wet and dry season in acoustically estimated biomass (top), fish length as approximated by acoustic TS (bottom). Bars represent standard error. 


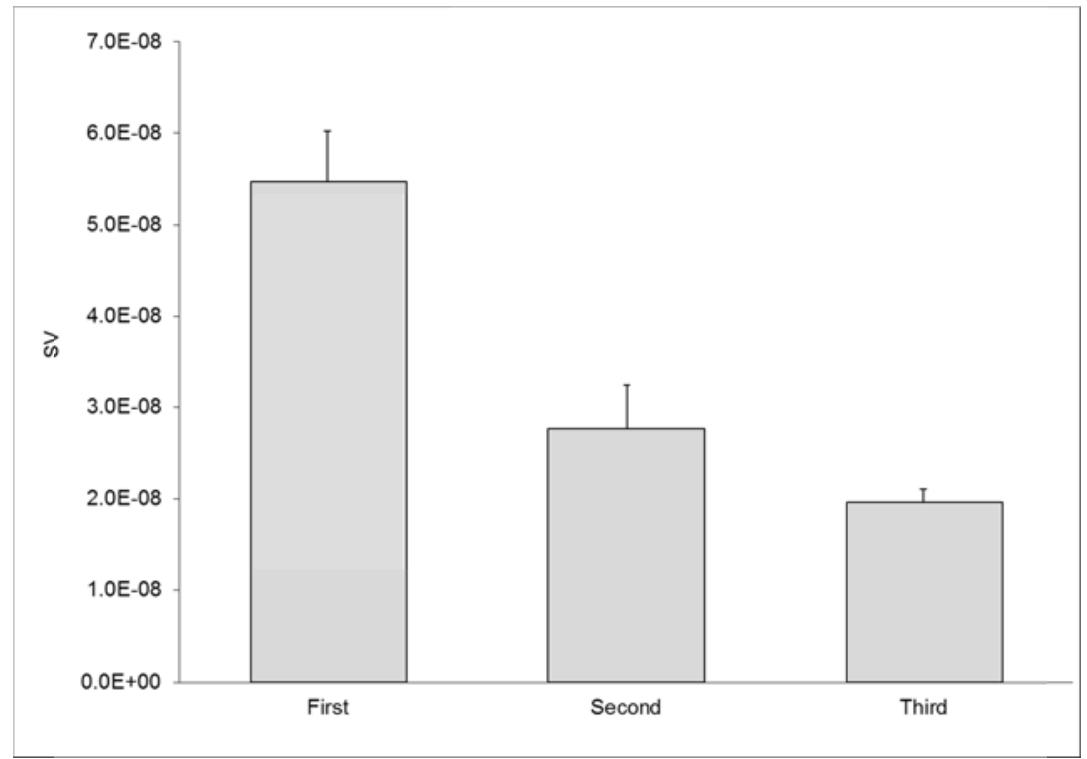

Figure 9.) Acoustic estimates of biomass, $\mathrm{S}_{V}$, across reef tracts. Bars represent standard error. 


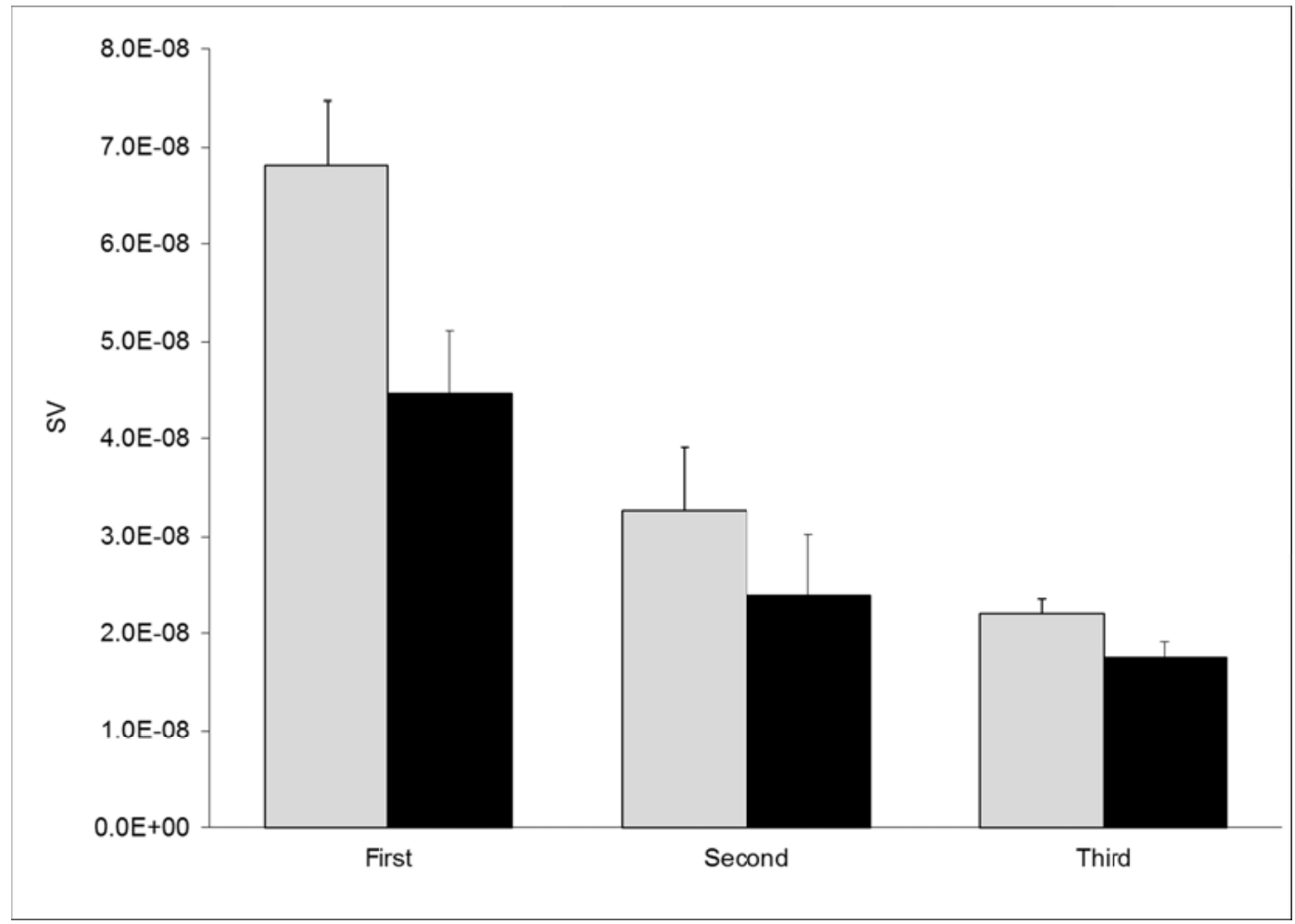

Figure 10.) Acoustic estimates of biomass, $\mathrm{s}_{\mathrm{v}}$ in both the dry (gray bars) and wet season (black bars). Differences between reef tract within each season were significant, however only the first reef showed significantly higher biomass estimates between season on the same reef tract. Bars represent standard error. 


\begin{tabular}{lc}
\hline \multicolumn{1}{c}{ Family } & \% biomass \\
\hline Pomacanthidae & 25.5 \\
Acanthuridae & 18.9 \\
Labridae & 13.1 \\
Haemulidae & 12.6 \\
Carangidae & 9.4 \\
Other & 19.0 \\
\hline
\end{tabular}

Table 2.) Percent biomass contributions between families observed in diver-based surveys. Biomass was estimated using standard length-weight relationships, and a total of 23 families were recorded. 


\begin{tabular}{lc|lc}
\hline \multicolumn{2}{c|}{ Wet Season } & \multicolumn{2}{c}{ Dry Season } \\
\hline Family & \% Biomass & Family & \% Biomass \\
\hline Pomacanthidae & 22.2 & Pomacanthidae & 33.5 \\
Acanthuridae & 19.7 & Acanthuridae & 21.2 \\
Carangidae & 17.1 & Labridae & 13.6 \\
Haemulidae & 13.6 & Haemulidae & 13.6 \\
Scaridae & 12.5 & Scaridae & 6.2 \\
Other & 14.9 & Other & 11.9 \\
\hline
\end{tabular}

Table 3.) Family contributions to biomass compared between seasons. Highlighted is the only noticeable difference being the replacement of the Carangids (Jacks) with the family Labridae (wrasses) in the dry season. 


\begin{tabular}{l|c|l|c|lc}
\hline \multicolumn{2}{c|}{ North } & \multicolumn{2}{c|}{ Haulover Inlet } & \multicolumn{2}{c}{ South } \\
\hline \multicolumn{1}{c|}{ Species } & $\begin{array}{c}\% \\
\text { Biomass }\end{array}$ & \multicolumn{1}{c|}{ Species } & $\begin{array}{c}\% \\
\text { Biomass }\end{array}$ & \multicolumn{1}{c}{ Species } & $\begin{array}{c}\% \\
\text { Biomass }\end{array}$ \\
\hline Pomacanthus Paru & 15.3 & Caranx ruber & 24.7 & Pomacanthus paru & 15.5 \\
Haemulon & 12.8 & Holocanthus ciliaris & 11.4 & Lachnolaimus maximus & 10.1 \\
flavolineatum & 10.7 & Pomacanthus arcuatus & 10.4 & Acanthurus chirurgus & 9.6 \\
Acanthurus bahianus & 7.3 & Acanthurus coeruleus & 8.4 & Acanthurus bahianus & 7.7 \\
Sparisoma viride & 7.2 & Lachnolaimus maximus & 5.1 & Holocanthus ciliaris & 7.1 \\
Canthidermis & 7.1 & Anisotremus virginicus & 5.1 & Acanthurus coeruleus & 6.9 \\
sufflamen & 4.5 & Sparisoma viride & 4.1 & Haemulon plumierii & 6.9 \\
Holocanthus ciliaris & 3.5 & Haemulon melanurum & 3.6 & Bodianus rufus & 4.6 \\
Acanthurus chirurgus & 3.1 & Haemulon carbonarium & 2.7 & Halichoeres garnoti & 3.8 \\
Mycoterperca bonaci & 2.5 & Acanthurus chirurgus & 2.5 & Selene vomer & 2.8 \\
Acanthurus coeruleus & Clepticus parrae & Other & 22.0 & Other & 25.1 \\
\hline
\end{tabular}

Table 4.) Percent biomass contributions between strata, with those species considered apex predators highlighted in gray. 


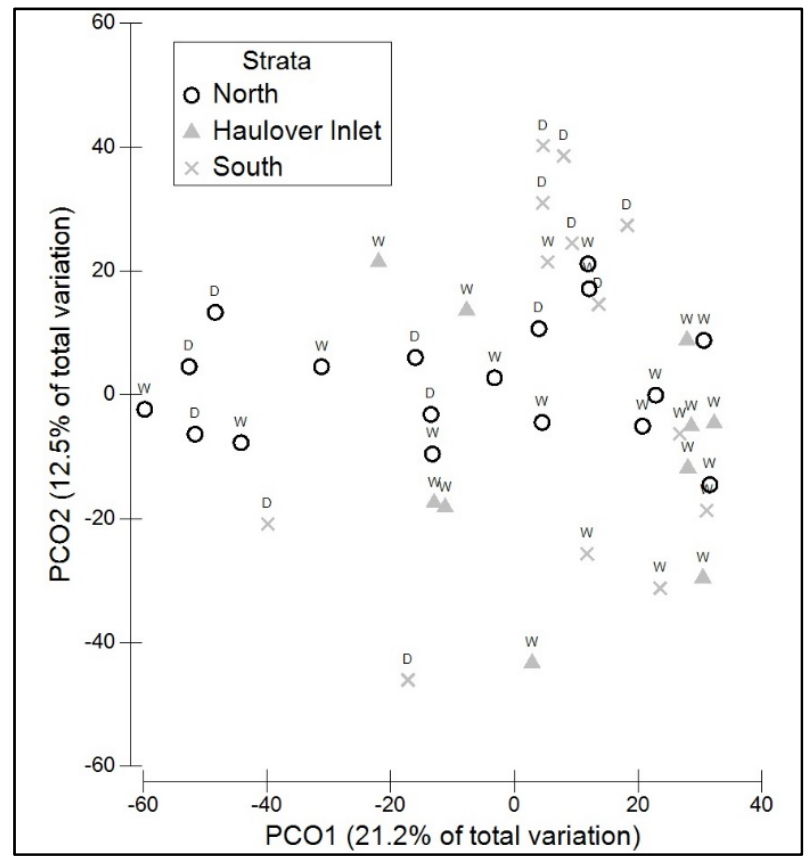

Figure 11.) Principle Components Ordination on the results of a Bray-Curtis Similarity matrix based on species abundances by survey site. A significant clumping of South strata (3) sites apart from other strata is evidenced, as well as a less clear but significant distinction between seasonal composition. 


\begin{tabular}{lcccc}
\hline Species & $\begin{array}{c}\text { Group Wet } \\
\text { Avg. } \\
\text { Abundance }\end{array}$ & $\begin{array}{c}\text { Group Dry Avg. } \\
\text { Abundance }\end{array}$ & Contrib. \% & Cum. \% \\
\hline Haemulon flavolineatum & 0.56 & 0.78 & 8.62 & 8.62 \\
Acanthurus bahianus & 0.78 & 1.75 & 7.97 & 16.6 \\
Acanthurus coeruleus & 1.60 & 1.13 & 6.52 & 23.1 \\
Canthidermis sufflamens & 0.19 & 0.76 & 6.31 & 29.4 \\
Sparisoma aurofrenatum & 0.15 & 1.41 & 6.09 & 35.5 \\
Chromis viridis & 1.30 & 0.12 & 5.80 & 41.3 \\
Sparisoma viride & 1.09 & 0.00 & 5.04 & 46.4 \\
Pomacanthus paru & 0.51 & 0.75 & 4.56 & 50.9 \\
\hline
\end{tabular}

Table 5.) Results of a two way crossed Bray-Curtis similarity percentage routine (SIMPER) showing the major contributors to differences between strata and season. These top 8 species contribute to over $50 \%$ of the differences in community composition at a site. 


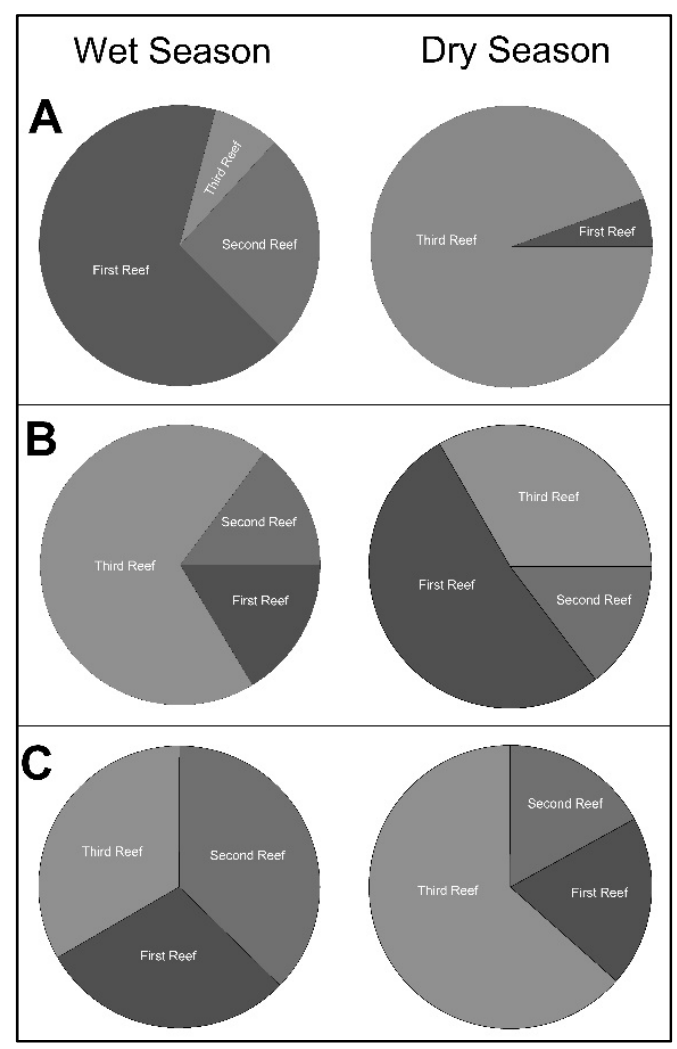

Figure 12.) Percent biomass contributions to reef tract of the top three SIMPER analysis species: $H$. flavolineatum (A), A. bahianus (B), and B. capriscus (C). 


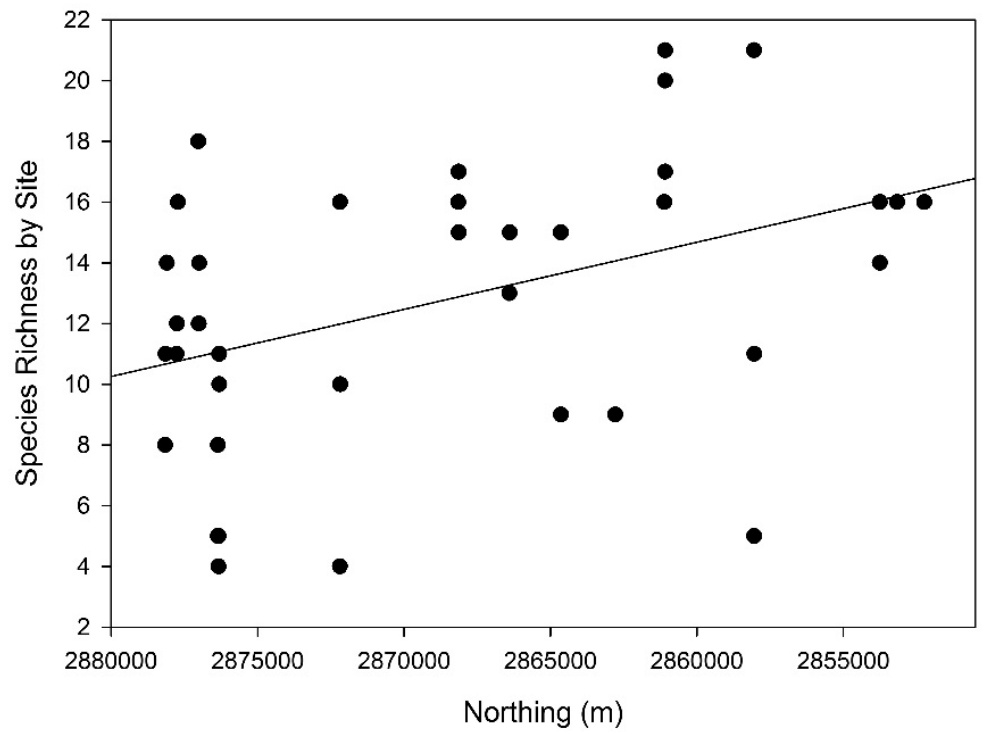

Figure 13.) Species richness across latitudes encompassed in the survey area show an increase in species richness with a decrease in latitude $\left(\mathrm{R}^{2}=0.1907, \mathrm{P}<0.05\right)$. 


\begin{tabular}{l|l|l|c}
\hline \multicolumn{2}{c|}{ North Miami-Dade } & \multicolumn{2}{c}{ Flower Gardens } \\
\hline \multicolumn{1}{c|}{ Species } & \% Biomass & \multicolumn{1}{c}{ Species } & $\%$ Biomass \\
\hline Pomacanthus paru & 11.4 & Paranthias furcifer & 28.4 \\
Caranx ruber & 9.27 & Kyphosus spectator & 12.2 \\
Holocanthus ciliaris & 8.51 & Clepticus parrae & 11.2 \\
Acanthurus coeruleus & 6.45 & Caranx latus & 5.73 \\
Acanthrus bahianus & 6.36 & Sphyraena barracuda & 5.71 \\
Acanthurus chirurgus & 6.10 & Mycteroperca bonaci & 4.55 \\
Lachnolaimus maximus & 6.05 & Lutjanus griseus & 3.32 \\
Pomacanthus arcuatus & 4.38 & Lutjanus jocu & 2.89 \\
Haemulon flavolineatum & 4.18 & Mycteroperca interstitialis & 2.20 \\
Sparisoma viride & 3.34 & Mycteroperca tigris & 2.08 \\
Others & 34.0 & Others & 21.8 \\
\hline
\end{tabular}

Table 6.) Comparison of percent biomass contributions by species in northern MiamiDade County and a remote reef on the Flower Gardens, TX. Highlighted in gray are species considered to be apex predators. 


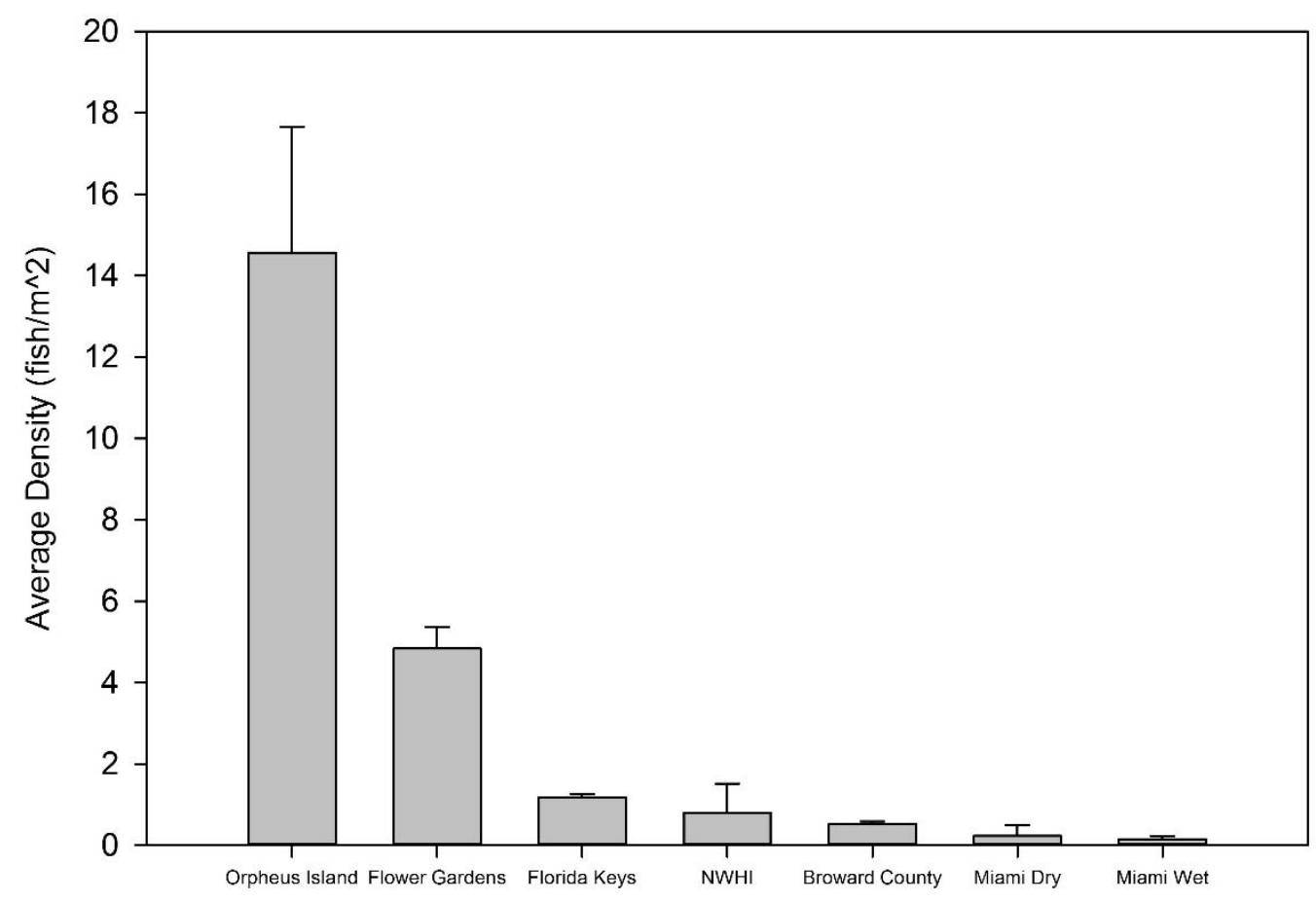

Figure 14.) Average fish densities recorded during diver-based surveys around the world. Plotted data include Orpheus Island, Great Barrier Reef (Ackerman and Bellwood, 2000), the Flower Gardens, Texas (NOAA, 2014), the Florida Keys (Burkepile et al., unpublished data), the northwest Hawaiian Islands (NWHI, Parrish et al., 2004), Broward County (Ettinger et al., 2001), and northern Miami in the wet and dry seasons. Bars represent standard error. 


\section{CHAPTER 4 - CONCLUSIONS, IMPLICATIONS, AND FUTURE DIRECTIONS Conclusions, Implications, and Future Directions}

In this thesis, I hypothesized that by creating a comparable metric of fish density between disparate survey methodologies, I would be able to better examine the dynamics of reef-associated fishes in shallow-coastal reef ecosystems. To this end, my results indicate that disparate methods of estimating fish density and biomass on a coral reef do indeed show similar distributional patterns as a function of reef tract (i.e., distance from shore) and of season. Although differences in magnitude were present between methods, fish density increased similarly in both acoustic and diver approaches, and I was able to detect variation as a function of distance to shore. It is possible that this increase is a result of the higher structural complexity of the third reef tract in comparison to the first and second tracts. Although the most narrow tract, a steep incline on the inshore and offshore edges of the third reef create the opportunity for complex microhabitat that may not exist on the first two tracts. Although not significant in explaining variance among reef density estimates, it is also possible that the increased depth on the third reef line is acting as a refuge for fish communities (Tyler et al., 2009). I was also able to detect the previously documented detrimental effect of water clarity on the ability of a diver to estimate fish densities on a reef, while the acoustics remained seemingly insensitive to water clarity in further support of the needed development of acoustics as a survey tool., (Bozec et al., 2011; Bernard et al., 2013).

I further hypothesized that reef fish communities would change as a function of season, and both methods were able to detect an increase in fish densities between the 
wet and dry seasons. A concurrent increase in fish size between the wet and dry season detected by both methods further corroborated this agreement in methods. Differences between seasons were not limited to densities, but were also observable in the variation of communities documented by divers. I was able to discern the top two contributors to these differences in community composition; both H. flavolineatum and A. bahianus are species known to undergo ontogenetic shifts, and differences in composition and density may be explained by the movements of these species across reef habitats over time (Nagelkerken et al., 2008). Northern sites showed higher concentrations of these species, however their contributions to community composition decreased towards the south. A potential explanation for this identified decrease is the proximity of the southern sites to seagrass beds in lower Biscayne Bay, as these species show preferential selection of seagrass habitat as juveniles (Huijbers et al., 2008).

While I hypothesized that proximity to regions of mixing with anthropogenically influenced waters would influence fish densities, we were not able to detect a preference or increase in fish densities in this region. In fact, both fish density and species richness was shown to increase as latitude decreased, which is in agreement with similar studies from Broward County.

Diver data obtained for this thesis gave an insight into previously undescribed fish communities in northern Miami-Dade County. Overall, reefs in Miami-Dade County exhibit declined reef health in comparison to geographically similar reefs, and reefs worldwide. Analysis indicates that the first reef tract may serve as a critical nursery habitat to important commercial species such as $H$. flavolineatum, especially in absence of extensive mangroves in the vicinity (Nagelkerken et al., 2002; Mumby et al., 2004). 
When compared to a comparatively healthy reef in the Gulf of Mexico (Flower Gardens), abundance data show communities in northern Miami-Dade County are dominated primarily by non-predatory fishes. Further, 7 of the top 10 contributors to biomass in the Flower Gardens are considered apex predators, compared to only 3 of the top 10 in northern Miami-Dade County. Predator declines may be associated with increasing anthropogenic pressure in Miami-Dade County, as is the case elsewhere in the Caribbean (Stallings, 2009). Predator removal in conjunction with other pressures can influence a shift from a coral dominated benthos to a macroalgal one (Dahlgren and Eggleston, 2000; McClanahan et al., 2002; Dulvy et al., 2004; Eriksson et al., 2009). This is of particular concern in a region where anthropogenic sources of nutrients have previously been tied to algal blooms and increased primary productivity on the reef (Lapointe et al., 2005). Finally, it is worth noting that density estimates from surveys in Miami-Dade County were the lowest of a literature values reported on undisturbed reefs worldwide. 


\section{References}

Bernard, A.T.F., Gotz, A., Kerwath, S.E., and Wilke, C.G. (2013) Observer bias and detection probability in underwater visual census of fish assemblages measured with independent double-observers. Journal of Experimental Marine Biology and Ecology 443: $75-84$

Bozec, Y.M., Kilbicki, M., Laloe, F., Mou-Tham, G., and Gascuel, D. (2011) Factors affecting the detection distances of reef fish: implications for visual counts. Marine Biology 158 (5): 969-981

Bernard, A.T.F., Gotz, A., Kerwath, S.E., and Wilke, C.G. (2013) Observer bias and detection probability in underwater visual census of fish assemblages measured with independent double-observers. Journal of Experimental Marine Biology and Ecology 443: $75-84$

Dahlgren, C.P., and Eggleston, D.B. (2000) Ecological processes underlying ontogenetic habitat shifts in a coral reef fish. Ecology 81(8): 2227-2240

Dulvy, N.K., Freckleton, R.P., and Polunin, N.V.C. (2004) Coral reef cascades and the indirect effects of predator removal by exploitation. Ecology Letters 7: 410-416

Eriksson, B.K., Ljunggren, L., Sandstrom, A., Johansson, G., Mattila, J., Rubach, A., Raberg, S., and Snickars, M. (2009) Declines in predatory fish promote bloom-forming macroalgae. Ecological Applications 19(8): 1975-1988

Huijbers, C.M., Mollee, E.M., and Nagelkerken, I. (2008) Post-larval French grunts (Haemulon flavolineatum) distinguish between seagrass, mangrove and coral reef water: Implications for recognition of potential nursery habitats. Journal of Experimental Marine Biology 357: 134-139

Lapointe, B.E., Barile, P.J., Littler, M.M., Littler, D.S., Bedford, B.J., and Gasque, C. (2005) Macroalgal blooms on southeast Florida coral reefs I. Nutrient stoichiometry of the invasive green alga Codium isthmocladum in the wider Caribbean indicates nutrient enrichment. Harmful Algae 4: 1092-1105

McClanahan, T., Polunin, N.C., Done, T. (2002) Ecological states and the resilience of coral reefs. Conservation Ecology 6: 18

Mumby, P.J., Edwards, A.J., Ernesto Arias-Gonzalez, J., Lindeman, K.C., Blackwell, P.G., Gall, A., Gorczynska, M.I., Harborne, A.R., Pescod, C.L., Renken, H., Colette, C.C. Wabnitz, Llewellyn, G. (2004) Mangroves enhance the biomass of coral reef fish communities in the Caribbean. Nature 427: 533-536 
Nagelkerken, I., Roberts, C.M., van der Velde, G., Dorenbosch, M., van Riel, M.C., Cocheret de la Moriniere, E., Nienhuis, P.H. (2002) How important are mangroves and seagrass beds for coral-reef fish? The nursery hypothesis tested on an island scale. Marine Ecology Progress Series 244: 299-305

Nagelkerken, I., Blaber, S.J.M., Bouillon, S., Green, P., Haywood, M., Kirton, L.G., Meynecke, J.O., Pawlik, J., Penrose, H.M., Sasekumar, A., and Somerfield P.J. (2008) The habitat function of mangroves for terrestrial and marine fauna: A review

Stallings, C.D. (2009) Fishery-Independent Data Reveal Negative Effect of Human Population Density on Caribbean Predatory Fish Communities. PLOS One 4(5): e5333

Tyler, E.H.M., Speight, M.R., Henderson, P., and Manica, A. (2009) Evidence for a depth refuge effect in artisanal coral reef fisheries. Biological Conservation 142: 652-667 